\title{
Heat Integration strategy for economic production of CHP from biomass waste
}

\author{
Jhuma Sadhukhan ${ }^{1 *}$, Kok Siew NG ${ }^{1}$, Nilay Shah ${ }^{2}$ and Howard J Simons ${ }^{3}$ \\ ${ }^{1}$ Centre for Process Integration, School of Chemical Engineering \& Analytical Science, The \\ University of Manchester, P. O. Box 88, Manchester, M60 1QD \\ ${ }^{2}$ Centre for Process Systems Engineering, Imperial College London, South Kensington Campus, \\ London SW7 2AZ \\ ${ }^{3}$ Ex Director of Sonhoe Development Company Ltd. 1 Berkeley Street, London, W1 8DJ
}

\begin{abstract}
The objective of this work was to design heat integrated, cost-effective and cleaner combined heat and power (CHP) generation plant from low cost $4^{\text {th }}$ generation biomass waste feedstocks. The novelty lies in the development of systematic site-wide heat recovery and integration strategies amongst biomass integrated gasification combined cycle processes so as to offset the low heating value of the biomass waste feedstocks. For the biomass waste based CHP plant technical and economic analysis, the process was based on low cost agricultural wastes like straws as the biomass feedstock and further established for a more predominant biomass feedstock, wood. The process was modeled using the ASPEN simulator. Three conceptual flowsheets were proposed, based on the integration of the flue gas from the char combustor, which was separately carried out from the steam gasification of biomass volatalised gases and tars, and carbon dioxide removal strategies. The cost of energy production included detailed levelised discounted cash flow analysis and was found to be strongly influenced by the cost of feedstock. Based on a combined energy generation of $~ 340-370$ MW using straw wastes priced at $35.3 £ / t$ or 40 Euro/t, with $8.5 \%$ and $8.61 \%$ by mass moisture and ash contents respectively, the cost of electricity generation was $4.59 \mathrm{p} / \mathrm{kWh}$ and $5.14 \mathrm{p} / \mathrm{kWh}$ for the cases without and with carbon capture respectively, with a $10 \%$ internal rate of return and 25 years of plant life. Based on the carbon capture value assigned by Carbon Credits Trading scheme, a much constrained viable price of $22 £ / t$ of such agricultural waste feedstocks for CHP generation was obtained, while up to $60 £ / t$ of waste feedstocks can be economically viable under the UK Climate Change Levy, respectively.
\end{abstract}

Keywords: biomass waste to CHP, biomass gasification combined cycle, Aspen simulation, heat integration and energy efficiency, economic analysis, carbon credit

\footnotetext{
* Author/s to whom correspondence should be addressed:

E-mail: Jhuma.Sadhukhan@manchester.ac.uk, Ph: +44 161306 4396, Fax: +44 1612367439
} 


\section{Introduction}

Gasification based combined cycle is an established route to thermo-chemically convert biomass (waste) into energy products, such as CHP [1]. Biomass gasification was practiced in the early decades of the $20^{\text {th }}$ century. Later, in the 1970 s, the second phase of biomass gasification commenced following the drastic increase in world oil prices and a growing awareness of possible climatic effects of continued use of fossil fuels. The plants that have been built were primarily based upon conventional biomass boilers and steam turbine cycles. The electrical efficiency of these plants is around 30\% [2] and the ratio of electrical energy to thermal energy generated is around 0.5 or below. Integrated gasification combined cycle, originally developed for fossil fuels, based on the gasification of solid fuels and combustion of the gas thus produced in gas turbines and following steam cycles is a promising way that offers opportunities for achieving higher efficiencies for CHP cogeneration [3]. This new interest was accompanied by an expansion of the devices considered for use with $4^{\text {th }}$ generation biomass (e.g. industrial and agricultural waste) gasification, beyond firing boilers and fueling internal combustion engines, such as, direct firing of gas turbines and fuel cells as well as polygeneration systems. Bridgwater and Evans have summarised recent activities on biomass gasification around the world that are either at a demonstration or commercial scale or have been developed to a point where they can, in principle, be demonstrated [4]. While a great deal of research effort has been spent on biomass CHP in the last two decades, there are very few operating without government support or subsidies [5]. Low heating value of the gas generated from biomass gasification, gas clean up for the removal of tar condensable and economics impose major barriers to the commercial implementation of biomass gasification based power plants. Intensive studies have been dedicated to the analysis, reduction and control technologies for tar based on gasifier design considerations and clean up technologies and successful applications have been presented at demonstration or commercial scale [5-7]. Economic analysis is also presented that shows that the potential for biomass energy lies in either processing low-cost wastes or relying on some sort of fiscal incentive, even if relatively large scales of operation and high-efficiency processes are assumed, for cost-effective production of electricity [8]. The main challenge in process design lies in identifying how the various processes are interlinked to affect the quality, amount and economics of energy production. In this study, our aim was to produce comprehensive modelling and integration strategies for various processes, such as, gasifiers, gas cooling and clean up technologies, gas turbines, heat recovery steam generators (HRSG), steam turbine and water networks, etc, in biomass based CHP plants. This paper considers the chemistry and operating variability of these processes and establishes the criteria for their selection for the delivery of a cleaner form of CHP. In particular, several 
integration strategies in view to maximize heat recovery and improve cleaner operation and economics of biomass gasification based combined cycle sites for CHP generation are investigated. The process integration strategies were developed based on no or nominal priced $4^{\text {th }}$ generation biomass resources such as, agricultural wastes like straws, and established for wood, as wood has been the predominant biomass feedstock extensively used as a standard fuel for electricity generation [9-10]. The detailed analysis of the results has been presented for straws and compared against the performance of wood.

The methodology comprising process simulation (in Aspen Plus), heat integration (in Aspen Plus and STAR, a software developed in the Centre for Process Integration at The University of Manchester) and economic analysis (in Excel) is used to develop three CHP generation flowsheets using biomass gasification based combined cycle can be produced. Figure 1 depicts the superstructure of the three flowsheets. The analysis relies upon a gasification process design consists of an air blown char combustor for the unreacted char and a steam gasifier for gas and tar from biomass, in two interconnected fluidised beds. Two options with respect to the injection of the flue gas from the char combustor can be adopted as shown in Options 1 and 2 respectively. The flue gas is injected at the gas turbine expander in Option 1, while it is mixed with the syngas after steam gasification in Option 2, respectively. With Option 2, both cases with and without $\mathrm{CO}_{2}$ capture were considered. The paper is structured as follows. The following section establishes the basis for selection of process flowsheets and integration strategies adopted. Section 3 illustrates the model based analysis methodology. Section 4 presents results and discussions on case studies on biomass utilisation to industrial CHP production. The final section 5 provides conclusions derived from this study.

\section{$\underline{\text { Figure } 1}$}

\section{Selection of Process Flowsheets}

The core of these flowsheets is the gasification process, which has the maximum impact on the energy recovery and gas quality. However, the reaction chemistry of gasification processes is not yet fully understood. This paper takes account of this aspect into modeling and aims at achieving best representation of biomass constituents and gasification process models using validation against experimental studies. There are hundreds of gasifiers in the patent literature. They can be divided into three principal types depending on the flow pattern: Updraft (countercurrent); Downdraft (cocurrent) and Fluidised bed [5, 9]. Ideally, the process should produce only a noncondensable gas and an ash residue. In reality, gas can be accompanied by condensable tar and particulate contaminants, which 
need to be washed and cleaned to a trace level before power generation from the gas turbines (although engines are known to be more tolerant of contaminated fuel gas [8]). Tar in the product gases condenses at low temperature, and leads to clogging or blockage in fuel lines, filters and engines. So they need to be removed before the gas turbines. Needless to say that the amount and chemical making of tar in the gas is a function of the temperature, residence time, thoroughness of circulation and mixing, degree of channeling, feed particle size distribution, uniformity of the bed, etc. which influence the choices of gasification configuration. In view of the thoroughness of mixing and good gas-solid contact, the use of fluidised bed gasifiers is a commonplace [8]. In fluidised bed gasifiers air/oxygen/steam levitate the incoming particles which are recirculated through the bed. With the fluidised bed, some of the tars produced in downdraft gasifiers and some of the char produced in updraft gasifiers can be oxidised, thus generating a moderate level of tar in the gas produced. These designs have various advantages, such as relatively simple construction, greater tolerance to particle size range than fixed beds, good temperature control and high reaction rates, high carbon conversion, high specific capacity, high conversion efficiency, limited turndown and very good scale-up potential [8]. In addition, only the fluidised bed configurations are being considered in applications that generate over 1 MWe [11-12]. Fluidised bed gasifiers are available from a number of manufacturers in thermal capacities ranging from 2.5 to $150 \mathrm{MWe}$ for operation at atmospheric or elevated pressures [9]. Atmospheric circulating fluid bed suppliers include TPS, Foster Wheeler, Battelle and Lurgi. Foster Wheeler has also developed a pressurised circulating fluid bed system.

The addition of steam, over and above that formed from the water and oxygen in a biomass feedstock, is essential to reform gas and tar and consequently reduce the tars. The remaining tar contained in steam gasification is rich in phenol, which is easy to reform catalytically. Also, steam is known to reduce the concentration of other forms of oxygenates including condensable.

Oxygen or air added to steam seems to produce more refractory undesired tars [5]. Oxygen needs to be added selectively to various stages, such as in secondary zones of a pyrolysis-cracker reactor, in order to preferentially oxidize tars. One of its main roles is to supply the heat through partial or full oxidation and therefore can be separately used to combust unreacted char.

This study presents the steam gasification cases with air driven char combustors in two interconnected fluidised bed reactors (Figure 2, [13]). Steam gasification has several advantages, such as higher $\mathrm{H}_{2}$ content and efficient tar and char reduction brought about by steam reforming [14]. However, the steam gasification reactions are endothermic as a whole. Hence, oxidation routes are utilised to provide heat for the endothermic steam gasification reactions. Use of air as a source of oxygen to burn 
biomass components (gas, tar and char) can give rise to a dilution with nitrogen of the product gas, lowering its caloric value. Dilution of hydrogen rich fuels resulting from coal or heavy hydrocarbon gasification processes with nitrogen prior to the entrance of the gas turbines may be desirable in precombustion carbon capture and storage (CCS) routes, in order to ensure safe operations of gas turbines. Such fossil fuel based large scale CHP plants comprising of gas turbines, heat recovery steam generators and steam turbine networks invoke the use of expensive air separation units for supplying oxygen to gasifiers and nitrogen and excess air to gas turbines. However, in the case of biomass, employing CCS technologies may not be necessary, as biomass is a carbon neutral fuel. The presence of carbon dioxide in the fuel gas to gas turbine serves the purpose of diluent replacing nitrogen and ensures acceptable heating value of the fuel gas to gas turbines.

Researchers have focused into the designing of gasification processes with two separate circulating fluidised bed reactors, which can avoid the need for air separation plant: (1) a gasification reactor in which the biomass can be converted into a high calorific value gas and residual char, and (2) a combustion reactor that burns the residual char to provide heat for gasification [13, 15-16]. The Battelle biomass gasification process, licensed in North America by Future Energy Resources Corporation (FERCO) in Atlanta, Georgia, USA is an example of such process technologies [15-16]. Murakami et al. [17] developed the dual fluidised bed gasification technology; the approach process consisted of two major components, a circulating fluidised bed acting as a combustor and a bubbling fluidised bed acting as a gasifier in which biomass is fed. The scheme in Figure 2 separates the combustion process and gasification process [13]. It is in a loop with end-to-end configuration composed of a circulating fluidised bed as a combustor, a cyclone, and a bubbling fluidised bed as a gasifier. The combustor is connected to the gasifier through the cyclone. The heat transfer between the two reactors is realised by a flowing inert medium, such as sand. The configuration reduces the diluting effect of nitrogen from air, and eliminates the need for an air separation plant when both air and oxygen are used as gasification mediums.

\section{Figure 2}

Tar removal has been recognised as an important aspect in the commercialization of biomass gasification technologies [8]. The trend is to rely on pressurised high temperature gasification systems for tar cracking with hot (fuel) gas filtration to deliver as hot a gas as possible to the turbine combustor and maximize efficiency, also considering the temperature requirements for alkali metal control and materials of construction of the filters $[8,9]$. Hence, conventional hot bag filtration was applied to 
clean the syngas from dust and particles. While careful consideration of high pressure ( 25-30 bar for 50-60 MWe power) and temperature $\left(>900^{\circ} \mathrm{C}\right)$ of the gasification process ensures generation of moderate heating value gas and avoids the need for a fuel gas compressor, sending hot gas to the gas turbine may not be an energy efficient design, because, ultimately cooling and dilution may be required to limit the temperature $\left(\sim 900^{\circ} \mathrm{C}\right)$ and thereby reduce $\mathrm{NO}_{\mathrm{x}}$ emission in the gas turbine combustors. Additionally, below $400^{\circ} \mathrm{C}$ is approximately where many of the compounds present in tar begin to condense [18]. Hence, syngas cooling below its dew point $\left(\sim 60-70^{\circ} \mathrm{C}\right)$ via high pressure superheated steam generation (at $\sim 650^{\circ} \mathrm{C}$ [19]) can be proved to be very effective with respect to heat recovery as well as cleaning of syngas. Research is into the development of Ultra-Steam Turbine (UST) and High-pressure / High-temperature Reheat Steam Turbines with new high temperature materials to expand the limits for steam temperature beyond $650^{\circ} \mathrm{C}$ [19]. The amount of steam generation from the syngas cooler and the outlet temperature of the syngas can be adjusted so as to meet the steam requirement of the gasifier at the least. The gasifier steam requirement is set to 0.6 times of the biomass weight [13] and at the gasifier pressure and a superheat temperature of $650^{\circ} \mathrm{C}$. This is followed by further cooling of the syngas with cooling water below its dew point. Syngas cooling below its dew point is not only an energy efficient way to recover high temperature heat into superheated steam, but this also helps to get rid of the water and tar condensable from the resulting fuel gas to gas turbines.

Direct quench with a part of the effluent recovered from cooling of syngas below its dew point, may be needed to remove tar condensates, toxins and other contaminants from the feed gas to gas turbines to a trace level (Figure 1). The effluent water after direct quench or indirect gas cooling is stored in a surge or settling drum to separate the tar condensates from the bottom of the surge drum. The water is then treated in an active carbon filter for residual toxin removal before being sent to the boilers. In Aspen simulation, $10 \%$ purge of effluent was considered from the waste water treatment plant, after which the purified water can be reused in steam production. The sludge can further be treated in swage treatment plant before being discharged to the environment. It makes an economic sense if integrated facilities for waste water and swage treatment plants can be shared with other industrial plants.

The heat recovery strategy from the syngas cooler, discussed above, reserves the most of the heat from HRSG for excess steam generation from a biomass based CHP site, which can be exported either as some steam and power with balance condensates returned as BFW to the site or entirely as power and condensates returned as BFW, using steam turbines. The condensates from steam turbines are returned as BFW to syngas coolers and HRSG. Some steam is required for the removal of sulphur compound 
(e.g. $\mathrm{H}_{2} \mathrm{~S}$ and traces of $\mathrm{COS}$ ), or combined with $\mathrm{CO}_{2}$. This steam can be supplied from the HRSG. Although it is not essential to remove $\mathrm{CO}_{2}$ from the biomass, as biomass qualifies as a carbon neutral fuel, the strategy of co-capture of $\mathrm{CO}_{2}$ and sulphur compounds may generate economic incentives via carbon credit [20-21]. Here, we presented a case study that includes the cost analysis of the Selexol process for the removal of combined sulphur compounds and $\mathrm{CO}_{2}$ [22-23], downstream compression, liquefaction and storage of $\mathrm{CO}_{2}$, together called as carbon capture and storage (CCS). Furthermore, we have examined whether $\mathrm{CO}_{2}$ reduction / capture can be achieved cheaply than the carbon credit expected for a biomass based CHP plant. The operating variables for various processes are listed in Table 1.The BFW recovery-steam generation-steam turbine power network is presented in Figure 3 (results of mass and energy balance are shown for Figure 1 Option 2 with straw as the biomass feedstock). The strategies for integration amongst biomass gasification combined cycle processes including (combined) $\mathrm{CO}_{2}$ and sulphur compound recovery process are summarised as follows (Figures 1 and 3).

\section{$\underline{\text { Table } 1}$}

\section{Figure 3}

1) A air blown char combustor for the unreacted char and a steam gasifier for gas and tar from biomass, in two interconnected fluidised beds, are used in order to avoid dilution of the resulting syngas with nitrogen and also at the same time avoid the use of an oxygen plant (air separation unit) for supplying pure oxygen to the gasifier.

2) For CHP generation, the temperature and pressure of the gasifier need to be decided based on the gas turbine feed gas specification on dry basis, explained later (e.g. Wobbe Index [24]). It has been observed that with increasing temperature and at lower pressure, the concentration of hydrogen in the syngas increases, hence, heating value of the syngas increases. However, a higher temperature $\left(>1000^{\circ} \mathrm{C}\right)$ may cause operational difficulties and maintenance problems, while increased pressure is associated with increased power generation from gas turbines.

3) Syngas from the gasifier is cooled below its dew point so as to allow the separation of water and tar condensable from the remaining fuel gas feed (rich in hydrogen) to gas turbines, leaving the gas clean and dry and improving its heating value (hence, Wobbe Index of the feed gas to gas turbines is verified on dry basis). This maximizes the heat recovery from the high temperature syngas from the gasifier and minimizes the heat loss during gas clean-up. Furthermore, due to the lower temperature of the feed gas to gas turbines, the temperature rise in the gas turbine combustor and consequently requirements for dilution with inert gas in order to lower $\mathrm{NO}_{\mathrm{x}}$ emission are restricted. 
4) The effluent water produced from syngas cooling below its dew point, after $10 \%$ purge and waster water treatment is recycled as BFW to recover heat from the syngas cooler into superheated steam.

5) The flue gas (rich in $\mathrm{N}_{2}$ and $\mathrm{CO}_{2}$ ) from the air driven char combustor is added to the inlet of the gas turbine expander if sufficiently clean or with the syngas from steam gasification if requires cleaning, in order to maximize the heat recovery and power generation. The latter scheme is not recommended for the processes / end uses where high purity hydrogen is required as it lowers the concentration of hydrogen in the product gas from the gasification. This flue gas is an excellent source of heat and can act as an inert to compensate for the lost effluent from the feed gas to gas turbines, thereby, adjust the Wobbe Index of the gas turbine fuel.

6) Combined $\mathrm{CO}_{2}$ and sulphur compound removal from the flue gas from the char combustor using the Selexol process [22-23] is studied. The Selexol process removes $\mathrm{H}_{2} \mathrm{~S}$ and most of the $\mathrm{CO}_{2}$ in the syngas stream [23]. A sulphur concentration of less than 1 ppmv is expected from the clean syngas [23]. A case with co-capture of $\mathrm{CO}_{2}$ and $\mathrm{H}_{2} \mathrm{~S}$ has been explored in this study with an interest to predict carbon credit from carbon neutral biomass fuels. The process can also operate at fairly low to medium temperature range, suitable to use on dry and cold syngas.

7) The heat recovery from HRSG and syngas cooler is maximised through high pressure superheated steam generation, which is then passed through back pressure steam turbines to generate additional electricity.

8) The use of fresh water is minimised based on maximum heat and BFW recovery strategies. After the recycle of the effluent, the balance of the BFW to syngas cooler is recovered from the steam turbine condensates.

9) Maximum heat recovery from the syngas cooler meets the entire high pressure superheated steam requirement by the gasifier. Excess steam may be generated via maximum heat recovery from syngas coolers (determined using composite curves [25]), which can be returned as BFW to syngas coolers after power generation through steam turbines. Alternatively, this steam can be exported as high pressure superheated steam with or without power generation from steam turbines.

10) The maximum amount of steam generating from HRSG is passed through back pressure steam turbines for power generation. From this steam turbine, a low pressure intermediate steam is extracted to meet the steam requirement by the (combined) sulphur compound (and $\mathrm{CO}_{2}$ ) recovery process. The balance of the condensate from the HRSG steam turbine is returned as BFW to syngas cooler and HRSG. Fresh supply of BFW may be required to recover the maximum amount of heat from HRSG.

11) Once the process heat from the syngas and the gas turbine exhaust is recovered into the maximum amount of steam generation from the boilers, i.e. syngas coolers and HRSG, the balance of the low grade heat from the gases can be recovered into the cooling water with a probable end use of district 
heating. This recovery of low grade district heat enhances the overall energetic efficiency of the plant, demonstrated in results and discussions. However, the price of district heat was not included into the economic analysis of the schemes studied, for a conservative estimation of the cost of electricity.

\section{Process Simulation}

The work had three major activities to select the most energy efficient and cost-effective biomass gasification based CHP system design. At first, a modular based simulation of basic process flowsheet is carried out using the Aspen Plus software package in order to establish mass and energy balance. Aspen is a standard process flowsheet simulation tool, widely adopted in the academic and engineering community and recently to simulate gasification based process sites [13, 26-27]. In the modular based simulation approach, key reaction and separation modules in a basic process flowsheet are identified and operating variables and interactions between modules can be optimised to achieve the desired product quality. Once mass and energy balance across a basic flowsheet is established, the energy related data from the heat source and sink processes and streams can be extracted and hereby, heat integration opportunities across overall sites can be identified, using thermodynamic based heuristics and tools (e.g. composite curves [25]). The objective of this energy integration exercise is the generation of maximum heat recovery networks around the processes, thereby enhancing energetic efficiency of the overall process. At the end of this exercise, the basic process flowsheets could be turned into fully developed flowsheets by including energy efficient CHP networks to the basic process flowsheet. Furthermore, economic analysis was carried out to investigate viability of these fully developed energy efficient process flowsheets. The methodology is presented in Figure 4.

\section{Figure 4}

\section{Simulation of Basic Process Flowsheet}

Simulation of the process flowsheet depicted in Figure 1: Option 2, with the flue gas from the char combustor added with the syngas from steam gasification and without any $\mathrm{CO}_{2}$ removal, in Aspen Plus is presented in Figure 5. The results are presented for straws. The various processes and streams are modeled as in Table 1. The interconnected circulating fluidised bed gasifier in Aspen Plus in Figure 5 comprises of two reaction modules: steam gasification of gas and tar and combustion of char with air, both modeled as RGibbs reactors. This way, the product composition and heat balance between the two reactor modules can be easily manipulated by controlling the temperature, pressure, 
steam to biomass ratio and oxygen to steam ratio of the gasifier. For convenience, the products (gas, tar and char) of primary pyrolysis were considered as feeds to RGibbs reactors (Table 1). Gas and tar were mixed and sent to steam gasification, while char was combusted with air in char combustor, both modeled as RGibbs reactors. The reason of why primary pyrolysis product distributions rather than biomass ultimate analyses were used as feed specifications to RGibbs reactors is that primary pyrolysis occurs as soon as biomass particles come in contact with the hot bed and before any mixing between biomass particles and reactants (steam and / or oxygen) occurs. Hence, the actual gasification reactions take place after devolatilisation or primary pyrolysis occurs. Primary pyrolysis process can be approximated as RYield reactors in Aspen, where yields and compositions of various products can be specified or calculated based on mass and component balance. Here, we have used Excel spreadsheet based calculations to predict the component distributions in various pyrolysis products, as an input to Aspen gasification model. A systematic representation of gasification reaction steps is illustrated in Appendix A.

The RGibbs reactor option works on the Gibbs free energy minimization principle. RGibbs reactor has been widely adopted to represent gasification reactions [13, 26-27]. However, RGibbs reactor representing an overall gasification process could be optimistic in case of biomass, because with this option thermodynamically more preferable exothermic reactions are selected over endothermic reactions. For example, if biomass ultimate analysis is presented as an input feed composition, no cracking or reforming reaction is taken into account and the various elements present in biomass $(\mathrm{C}$, $\mathrm{H}, \mathrm{O}, \mathrm{N}$ and $\mathrm{S}$ ) are treated as pure components. Oxidation reactions are selected over steam gasification, e.g. cracking and reforming reactions (except the water gas shift and methanation reactions, which are exothermic), using elemental oxygen present in biomass analysis, even though the reactions were carried out in the absence of oxygen.

Researchers have found better representations of gasification processes by breaking up biomass into different components and dealing with them separately. Nikoo and Mahinpey [26] dealt with gas and char separately, with hydrodynamic and kinetic models developed using Aspen Custom Modeler. Tar was likely to be included as a part of char in their study. In this case, we have separately modeled the devolatilisation or primary pyrolysis products: volatile gas, tar and bottom of biomass (char as carbon in Table 1) according to Table 2 [28]. Tar was modeled in two ways, using proximate and ultimate analyses [13] and as chemicals, such as, phenol as revealed in numerous studies [7, 28-29]. Tar composition is complex to model, because it varies with the source and type of biomass, equivalence ratio (ratio of oxygen in the mixture to the stoichiometric oxygen requirement [5]), temperature and 
steam to biomass ratio and many other factors [30-32]. Although a number of alternative approximate representations of tar exist, many important studies have recognised that a comprehensive tar characterization is imperative and yet to establish $[5,8,18]$. With phenol as the model compound of the tar in this study, the effect of equivalence ratio and bed temperature on the gas composition and tar content of the product gas can be described well [28-29]. One key aspect of the representation of tar in terms of chemical constituents rather than elemental (ultimate) analysis in Aspen simulation is the consideration of tar reforming reactions in the steam gasifier, which otherwise can not be accounted for, using RGibbs reactor. Thus, the tar represented as phenol in this simulation study takes account of its reforming reaction, resulting into endothermic performance of the steam gasifier. Finally temperature and pressure of the gasifier are decided in order to meet the fuel gas specification (on dry basis because water and condensates are removed from the fuel gas) of the gas turbine (Wobbe Index [24] predicted as in Table 3). The variation of gasification product composition with temperature at two different pressures is illustrated for straw as the biomass feedstock in Figure 6.

The formation of tar is one of the major problems to deal with during the biomass gasification process [33]. Use of catalysts can eliminate / break down tar in biomass gasification processes to an extent, however at the cost of catalyst deactivation and fouling by the carbon build-up on the surface of the catalyst [34-38]. Tar in the product gases condenses at low temperature, and leads to blockage in fuel lines, filters and engines. Also, it reduces the utilization efficiency of biomass. Therefore, the reduction or decomposition of tar in biomass derived fuel gases is one of the biggest obstacles in its utilization for power generation. Han and Kim [7] have presented a comprehensive review on the reduction and control technology of tar during biomass gasification / pyrolysis. Among many ways, such as, mechanism methods, self-modification, thermal cracking, catalyst cracking and plasma methods, discussed in their work, our simulation framework can be used for thermal and catalytic cracking of tar and heat integration of the overall gasification process (gasification of gases and tar and combustion of char). Additionally, we have considered condensation of syngas below dew point in the syngas cooler, in order to ensure separation of the tar condensable from the gas turbine fuel gas, although gas turbines are known to be less susceptible to tar condensable.

\section{Figure 5}

\section{$\underline{\text { Table } 2}$}

$\underline{\text { Table } 3}$

\section{Figure 6}




\section{Heat Integration}

Heat integration was carried out to recover the maximum amount of heat from the two major boilers, syngas cooler and HRSG, which produced high pressure superheated steam at 65 bar (can be at supercritical state of $>100$ bar, however, not considered in this study) and at $650^{\circ} \mathrm{C}$ and 5 bar and $250^{\circ} \mathrm{C}$, respectively. These superheat temperatures and pressures of steam were decided based on the temperature and pressure conditions of the two boilers. The syngas cooler operates at the same temperature and pressure as the gasifier (which is a high temperature and pressurised gasifier), while the gas turbine flue gas to HRSG is at slightly above atmospheric pressure and at a temperature $\sim 400$ $450^{\circ} \mathrm{C}$. The exit temperature of the gases from the boilers is predicted based upon maximum heat recovery using composite curve analysis and a minimum temperature approach between hot gas and cold water-steam [25]. The balance of the heat from the gases after maximum heat recovery from them is rejected to cooling water, which after heat extraction can be used for district heating. Figure 7(a-b) presents the composite curves across syngas cooler and HRSG respectively for the case in Figure 1: Option 2 with straw as the biomass feedstock. The pinch points with minimum temperature approaches of $\sim 100^{\circ} \mathrm{C}$ and $25^{\circ} \mathrm{C}$ between the hot gas and cold water-steam are assumed for syngas cooler and HRSG respectively. A higher temperature driving force is assumed for the former due to its hot syngas intake and thereby high maintenance requirement. Figure 7(a) presents two curves for steam generation: one fulfilling minimum steam requirements of the gasifier, the other is with excess steam generation by $40 \%$ more than the minimum requirement. The latter is the strategy adopted to maximize heat recovery from the boilers. The low temperature heat rejected to cooling water, which can be used for district heating, is also illustrated for the syngas cooler in Figure 7(a).

Once the maximum steam generation and minimum cooling water requirements of the boilers are established through heat integration, the BFW (condensate) recovery-steam generation-steam turbine power network is derived as in Figure 3 (for the case in Figure 1 Option 2: without any $\mathrm{CO}_{2}$ removal and with the flue gas from the char combustor added with the syngas from steam gasification, based on straws as the biomass feedstock). Maximum steam generation also allows maximum potential for power generation from steam turbines. In general, where steam generated from syngas coolers and HRSG is in excess, the excess steam can be exported, or used to generate additional power from steam turbines. After power generation, lower pressure steam can be exported, or extracted into maximum power generation using back pressure turbines. Condensates recovered after power generation from steam turbines is returned as BFW to syngas cooler and HRSG. Maximum power generation through condensing steam turbines leads to maximum condensate recovery, hence, minimum BFW 
requirements. Hence, extraction of intermediate steam from steam turbines is associated with the reduced power generation and increased BFW requirements, however, with increased steam production. The choice of steam production against power generation is very much dependent on the price and potential for exporting steam against power. In this work, we have presented maximum power generation option for the three cases (Figure 1: Option 1 and Option 2 without or with $\mathrm{CO}_{2}$ capture).

The power generation results from steam turbines obtained from Aspen simulation were validated using STAR, a software package developed in the Centre for Process Integration at The University of Manchester, which used the mass flow rate, temperature and pressure of inlet and outlet steam and outlet pressure of condensate to predict power generation (Table 1 and Figure 3). STAR provides the analytical and optimisation tools for the design of the site utility and cogeneration systems (The University of Manchester, 2008). A heat integration study using the above steps resulted into fully developed process flowsheets that included BFW (condensate) recovery-steam generation-steam turbine power network presented in Figure 3 (for the case in Figure 1 Option 2: without any $\mathrm{CO}_{2}$ removal and with the flue gas from the char combustor added with the syngas from steam gasification, based on straws as the biomass feedstock).

\section{$\underline{\text { Figure } 7}$}

\section{Economic Analysis}

Once a heat integrated complete flowsheet is developed, economic analysis is performed for the prediction of the cost of electricity generation from different options. The assessment comprises of the operating and capital costs, followed by the discounted cash flow analysis.

\section{Operating Costs}

A heat integrated biomass based CHP generation site incurs operating costs due to biomass feedstocks predominantly. Feed costs for short rotation forestry wood and conventional forestry wood have been reported by Aberdeen University [39] and also by Kaltschmitt [40] for various European countries. The costs vary widely by country, ranging from 10-20 /odt through to over 160 /odt (odt: oven dry tonne). Mean costs are 70 /odt. It is unlikely that a novel technology would be demonstrated in an area where biomass feed costs are high. Thus a feed cost of 40 /odt is more reasonable to assume. In this 
case, we have based our studies on cheap agricultural biomass waste like straws, which can be available without any price associated with it. However, an analysis of the effect of feed cost on the electricity production cost has been presented to show the impact of a wide range of feed costs [0-50 $£ / t$. This would also allow taking account of any transport cost associated with the delivery of the biomass feedstock at the point of use. Furthermore, once straw like no or nominal priced agricultural waste feedstocks can be established as a valuable source of electricity generation, the grower must also expect some income out of their disposal.

In addition to biomass feedstock cost, the other operating costs associated are due to BFW and cooling water. The heat integration exercise minimizes the requirement for both, as illustrated in Figures 3 and 7. From Figure 7 the cooling water requirements for cooling syngas and gas turbine exhausts after maximum heat recovery are predicted in terms of enthalpy, which is then converted into the amounts of cooling water using a specific enthalpy of cooling water of $\sim 168 \mathrm{~kJ} / \mathrm{kg}$. The price of BFW and cooling water is set at 0.35 and $0.05 £ / \mathrm{m}^{3}$ respectively.

\section{Capital Costs}

The capital costs of individual processes, such as feed handling and drying, gasification, boilers, gas clean up units, gas and steam turbines and waste water treatment unit are estimated based on extensive study report by NREL and similar other reports [10, 41-46]. The capital costs of individual processes in the corresponding years were collected from these references and levelised using the present annual cost index [47] and the indices in the previous corresponding year [48-49]. The capital cost analysis for Figure 1 Option 2, with and without carbon capture based on straws as the biomass feedstock is presented in Table 4. The costs of gasification (pressurised fluidised bed gasifier with air driven char combustor), feed handling and drying and waste water treatment processes were estimated based on NREL study report [10]. The costs of cyclone, syngas baghouse filter and condensing scrubber were predicted using the relationship between cost and capacity, as in equation (1) [41-42].

$$
\frac{\operatorname{COST}_{\text {SIZE }_{1}}}{\operatorname{COST}_{\text {SIZE }_{2}}}=\left[\frac{\text { SIZE }_{1}}{\text { SIZE }_{2}}\right]^{R}
$$

where SIZE2 and SIZE1 are the system throughput and the base system throughput ( $8.4 \mathrm{~kg} / \mathrm{s}$ of wood), respectively. $C O S T_{S I Z E 2}$ and $C O S T_{S I Z E 1}$ are estimated cost of the system and the cost of the base system, $R$ is the scale factor, 0.7 and 0.65 for cyclone-condensing scrubber and baghouse filter respectively. Sinnott [42] provided the correlations for estimating the cost of boilers (HRSG and SYNGCOOL). The cost of sulphur removal is given by Simbeck and Chang [43]. The costs of gas 
turbines and steam turbines are estimated based on the correlations given by NETL [44]. Boilers, gas turbines and steam turbines are assumed to have a number of sub-units for cost estimation purposes. The cost of CCS was assumed based on an average cost of $£ 10.5$ per MWh electricity (IPCC [45]). The total annual electricity generated was found to be 568004.2 MWh for the case with $\mathrm{CO}_{2}$ capture, by assuming 8000 operating hours per annum. The indirect capital costs were calculated based on the estimation provided by Bridgwater et al. [46]. Total plant cost included the detailed direct production costs, costs of general facilities, installed plant cost, commissioning, contingency, contractors' fees and interest during commission, etc [9].

$\underline{\text { Table } 4}$

\section{Discounted Cash Flow Analysis}

Discounted cash flow calculations (DCF) were carried out to include the annualised capital charge in the form of tolling fees into the cost of electricity generation [50-52]. The discount rate was assumed to be $10 \%$ for 25 operating years (IEA, [53]). The operating years were taken as 25 years because most of the major vessels and equipment would have a design life of 25 years. The DCF analysis is merely based on CAPEX. The construction period was assumed to be 3 years. The CAPEX in the year $-2,-1$ and 0 during the construction period were taken to be $20 \%, 45 \%$ and $35 \%$ respectively, of the total CAPEX, respectively (IEA, [53]). For a given Internal Rate of Return (discount rate) of 10\% [18], a construction period of 3 years before plant start up $\left(0^{\text {th }}\right.$ year corresponds to the plant start up), a plant life of 25 years after start up and a construction policy of $20 \%, 45 \%$ and $35 \%$ investments of total capital in the years $=-2,-1,0$ respectively, the simple cash flow and discounted cash flow in various years is presented in Figure 8. Biomass plants are either adjunct facilities or stand-alone plants. Adjunct facilities take at least 18 months to build, while a stand-alone plant usually takes 24-30 months to construct (GAIN report: RP7029, 2007 [54]). For a fully developed biomass CHP plant, a completion period of 36-40 months is expected including commissioning, similar to integrated bioenergy facilities (Hamelinck et al, [55]). The net present value (NPV) of a plant is calculated by the cumulative cash flows, simple or discounted. Hence the simple and actual payback time when NPV is zero, is 9.1 and 25 years respectively from the year of plant start up or 12.1 and 34 years respectively in total as shown in Figure 8. An annualised capital charge of $11 \%$ is predicted that satisfies the above conditions discussed. This percentage annualised capital charge multiplied with total cost of a plant (Table 4) provides the tolling fees (in $£ / y$ ) of the plant. Finally, the cost of electricity generation (per annum) is determined from the summation of the operating cost and tolling fees. The difference in the 
cost of electricity generation between the two sites with and without $\mathrm{CO}_{2}$ capture reveals the cost of $\mathrm{CO}_{2}$ capture.

\section{Figure 8}

\section{Results and Discussions}

Our study was focused on the agricultural waste. The biomass analysed in this case was straw [13]. The study was also established with wood as a reference biomass feedstock [9]. The proximate analysis and the ultimate analysis of the biomass feedstocks under consideration are provided in Table 5 [13]. The process operating variables were provided in Table 1.

\section{$\underline{\text { Table } 5}$}

Gasification product composition versus temperature at 2 different pressures, 1 bar and 30 bar, respectively, based on straws as the biomass feedstock, as obtained from Aspen simulation is presented in Figure 6. Tar was represented in terms of ultimate analysis (Table 2) as well as phenol (with mol fractions of phenol, steam and oxygen of $46 \%, 21 \%$ and $33 \%$ ). We varied the gasifier temperature between $750^{\circ} \mathrm{C}$ to $950^{\circ} \mathrm{C}$ with the steam to biomass weight ratio of 0.6 [13]. Both representations of tar had no effect on the gasification product composition, however, with tar representation in terms of ultimate analysis, the overall reactor performance became highly exothermic, which contradicted the actual nature of the gasification process. With tar representation as phenol, cracking and reforming (steam gasification) reactions were taken into account and hence, the overall performance of gasification process became thermally neutral, with the heat from char combustor supplying heat to steam gasification. Further illustration on this was given in section 3.1.

The hydrogen concentration in the syngas from the gasifier was found to stay steady with the temperature of the gasifier, at $56.5 \%$ compared to 60.5 in the reported results [13] at atmospheric pressure. However, the reported hydrogen concentration could be optimistic as tar was not taken into consideration in their simulation. The effect of the pressure of the gasifier has a more profound effect on the concentration of the syngas. With increased pressure of the gasifier to $30 \mathrm{bar}$, the hydrogen concentration in the syngas was found to increase from $40 \%$ to $52.5 \%$ with increasing gasifier temperature from $750^{\circ} \mathrm{C}$ to $950^{\circ} \mathrm{C}$. Although a lower concentration of hydrogen was observed at a higher pressure of the gasifier, a high gasification pressure has advantage of increased power 
production from the gas turbines. Hence, a pressure of 30 bar for the gasifier was decided while keeping the temperature below $1000^{\circ} \mathrm{C}\left(950^{\circ} \mathrm{C}\right)$ (illustrated in section 2). It also generated an acceptable Wobbe Index of 9.14 and 11.45, of the feed gas to gas turbine, for the cases without and with $\mathrm{CO}_{2}$ capture respectively in Figure 1 Option 2 (Table 3). Furthermore, with the increase in temperature, Boudouard reaction (Appendix A) that consumes $\mathrm{CO}_{2}$ became more dominant, increasing $\mathrm{CO}$ and decreasing $\mathrm{CO}_{2}$ with the temperature. The product composition from the biomass gasifier is the result of the combination of a series of complex and competing reactions, as given in Reaction sets 1-3 in Appendix A. Except the water gas shift and methanation reactions, the steam gasification reactions are highly endothermic, while the oxidation of char is exothermic supplying heat to the steam gasification reactions. Endothermic reactions were favoured at the higher gasifier temperature, which resulted in an increase of $\mathrm{H}_{2}$ and $\mathrm{CO}$, and a decrease of $\mathrm{CO}_{2}$ and $\mathrm{CH}_{4}$. The results of product composition showed good agreement with the published literature with $\mathrm{CO}$ increasing evidently with the gasifier temperature, whilst $\mathrm{CO}_{2}$ and $\mathrm{CH}_{4}$ decreasing correspondingly. The syngas compositions after clean up, cooling and effluent recovery and before feeding to gas turbines for the two options (without carbon capture) in Figure 1 for straw and wood as the biomass feedstocks are given in Table 6. The performance of wood is obviously superior compared to straws, due to its high carbon and hydrogen concentration in the biomass. The high moisture content of wood is compensated by the high ash content of straws.

\section{$\underline{\text { Table } 6}$}

The combined heat and power generation efficiency is in the range of $38-40 \%$, with wood having efficiencies 3\% higher than straws in each case (Table 7). The CHP generation efficiency in Table 7 is calculated from the total power generation from the gas turbines and steam turbines, (e.g. 191.578 MW in Figure 5 and 55.129 + 124.404 MW in Figure 3, for straws in Option 2), subtracted by the power consumption due to air compression (for gas turbine expander and char combustor, 115.103 and 15.462 MW in Figure 5) and pumps (0.119 and 0.024 MW in Figure 5) (and CCS); the total district heat generation from the syngas cooler and HRSG (35.05 and 93.58 MW in Figure 7a-b); and from the LHV of the feedstock (919.8 MW calculated from Table 5). The electrical efficiency obtained for wood is $31-33 \%$, comparable with the case reported in [2]. The energy available for district heating can be predicted from the energy extracted (in the form of sensible heat) into cooling water, as obtained from composite curve analysis in Figure 7. Cooling water can be heated above or at least to $\sim 60^{\circ} \mathrm{C}$ (dew point of syngas and GT exhaust gas), which can be made available as a low grade district 
heat. From here onwards, we would present the inferior case with straws as the biomass feedstock for a conservative assessment of the cost of electricity generation.

The maximum amount of high pressure superheated steam generation from syngas cooler and HRSG at $65 \mathrm{bar}-650^{\circ} \mathrm{C}$ and $5 \mathrm{bar}-250^{\circ} \mathrm{C}$, respectively, was established using composite curve analyses. An example of the case without $\mathrm{CO}_{2}$ recovery in Figure 1 Option 2 with straws as the biomass feedstock was illustrated for syngas cooler and HRSG in Figure 7(a)-(b) respectively, in section 3.2. The corresponding minimum cooling water requirements / available district heat generations mentioned above were also established. Once the excess steam available for power generation, condensate recovery after maximum power generation through condensing steam turbines and minimum BFW requirements of a site were established, Figure 3 was generated with all the balance of BFW, cooling water and steam turbine power network (for the case in Figure 1 Option 2, without $\mathrm{CO}_{2}$ recovery based on straws as the biomass feedstock). The results of maximum heat recovery analyses for the three cases depicted in Figure 1 Options 1-2, with flue gas from char combustor injected to GT expander and flue gas from char combustor mixed to syngas, without and with $\mathrm{CO}_{2}$ removal, respectively, based on straws as the biomass feedstock are presented in Table 7. As expected, Option 1 results into maximum power generation from the gas turbines due to the increased flow through gas turbines, while Option 2 with $\mathrm{CO}_{2}$ capture generates the least power from the gas turbines due to the removal of bulk of $\mathrm{CO}_{2}$ from the feed gas to gas turbines. As can be seen, the flowrates of feed gas to gas turbines have dominating effect on the power generation than the heating value, which is higher in the latter case. This is because, the Wobbe Index of the feed gas to gas turbines in all cases was within $\sim 10 \%$ limit from the reference case [24] reported in Table 3. Power generation from steam turbines is the lowest in case of Option 1 in Figure 1, due to lower heat recovery from the syngas cooler. Power generation from steam turbines is predominant so as to offset the reduced power generation from gas turbine in case of Option 2. Additionally, Option 1 was based on the assumption that the flue gas from the char combustor does not contain any condensable tar and is a result of complete combustion of the char combustor. As a safer option, thus Option 2 was recommended for CHP generation and further analysed for economic evaluation.

A comparison of economics between the two cases without and with $\mathrm{CO}_{2}$ capture in Figure 1 Option 2 with straws as the biomass feedstock is presented in Table 8, using the illustrations provided in section 3.3. The capital investments for the two cases without and with $\mathrm{CO}_{2}$ capture are 209.37 and 217.8 million $£$ respectively, which are comparable with the cost estimates by Bridgwater et al [9]. The cost of electricity generation varies strongly with the given internal rate of return or the annualised charge 
predicted, for example, this cost becomes 1.52 and $1.76 \mathrm{p} / \mathrm{kWh}$ from 1.35 and $1.56 \mathrm{p} / \mathrm{kWh}$ as an IRR changes from 12 to $10 \%$, for the cases without and with $\mathrm{CO}_{2}$ capture, respectively, for a nominal feedstock cost of $1 £ /$ t. As can be noted, the cost contribution from capital investment shifts from $\sim 88$ $\%$ to $\sim 26 \%$, as the feedstock cost is changed from a nominal value of $1 £ / t$ to a more reasonable value of $35.3 £ / t$ or 40 Euro/t [9] (Table 8$)(£ 1=1.134$ Euro). The corresponding costs of electricity generation are 1.35 and $4.59 \mathrm{p} / \mathrm{kWh}$ for the cases without $\mathrm{CO}_{2}$ capture and 1.56 and 5.14 for the cases with $\mathrm{CO}_{2}$ capture respectively and for $10 \%$ internal rate of return and 25 years of plant life or $11 \%$ annualised charge predicted (section 3.3.3, Figure 8). Based on this difference in the cost of electricity generation and $30.1 \mathrm{t} / \mathrm{hr}$ of $\mathrm{CO}_{2}$ capture, between the two cases, the corresponding cost of carbon capture was estimated as 5.76 and 15.44 Euro/t of $\mathrm{CO}_{2}$ for the feedstock costs of 1 and 40 Euro/t respectively. Hence, $\mathrm{CO}_{2}$ can only be captured cost-effectively with respect to a carbon credit value of $<15$ Euro/t, when feedstock cost is $<40$ Euro/t. According to Argus, 2009, EU ETS price index, a value of 11.65 Euro/t of $\mathrm{CO}_{2}$ is assigned for estimating the $\mathrm{CO}_{2}$ emission trading value in the market [56]. Hence, according to this current Carbon Credits Trading value of 11.65 Euro/t of $\mathrm{CO}_{2}$, a straw like biomass waste feedstock cost must be lower than 22 Euro/t. The variations in the cost of electricity generation for the two cases with and without $\mathrm{CO}_{2}$ capture and thereby the cost of carbon capture with respect to the feedstock price predicted, are presented in Figure 9. The price of electricity purchased by manufacturing industry in the UK as per DTI energy prices varied between 4.84 in 2006 to $7.13 \mathrm{p} / \mathrm{kWh}$ in the third quarter of 2008 (excluding the Climate Change Levy), while with the full rate of the levy the maximum electricity price reported was $7.59 \mathrm{p} / \mathrm{kWh}$ [57]. Based on this trend, upto a maximum of $60 \mathrm{f} / \mathrm{t}$ of feedstock cost can be acceptable. Straw like agricultural waste, $4^{\text {th }}$ generation bioenergy feedstock generally associated with no or nominal price can therefore be transported conveniently. Thus, based on a price variation of 1-35.3 $£ / t$ of such a $4^{\text {th }}$ generation biomass waste feedstock, upto a maximum of 19-11 p/kg transportation cost can be acceptable, with the support of the UK Climate Change Levy. Furthermore, once straw like low cost agricultural waste feedstocks can be established as a valuable source of electricity generation, the grower must also expect some income out of their disposal.

\section{Table 7}

$\underline{\text { Table } 8}$

Figure 9

\section{Conclusions}


This paper establishes a process simulation, heat integration and discounted cash flow analysis based methodology for integrated design of biomass to CHP generation technologies. Extensive integration strategies between processes in a biomass waste based combined cycle site have been established based on the following criteria, maximum heat recovery and cleaner and cost-effective production of CHP. In this study, useful heat in the form of steam was considered for power generation from the site. The site is based on integrated gasification combined cycle, which is composed of the following major processing areas: gasification, gas cooling and cleans up technologies, combined co-capture process for sulphur compounds and $\mathrm{CO}_{2}$, gas turbines, heat recovery steam generators (HRSG), steam turbines and boiler feed water (BFW) recovery networks. A circulating fluidised bed reactor with integral char combustion was selected for biomass gasification. The impact of representations of gasification feedstock chemistry and its process operating conditions was analysed for validating heat and material balance across gasification. The representation of tar in terms of its chemical constituents also helps to take account of the endothermic steam cracking and reforming reactions in the modelling of the steam gasification process. Two cases were studied with flue gas from char combustor injected to gas turbine expander and mixed up with the syngas from steam gasification respectively. The latter case was further selected for carbon capture and consequently for economic analysis, due to its cleaner operation. Maximum heat recovery was performed for the gasifier with no net heat requirement and for the syngas cooler (condensing syngas below its dew point) and HRSG via high pressure superheated steam generation. Condensation of syngas below its dew point was evaluated to predict the recovery of effluent after waste water treatment. Maximum heat recovery is associated with minimum BFW and cooling water requirements for the site. Maximum heat recovery via syngas cooling below its dew point is also accompanied by several other benefits in gas turbine operations, including removal of tar condensables and cleaner operation of gas turbines, as follows. It prevents temperature rise and consequently $\mathrm{NO}_{\mathrm{x}}$ emission from gas turbine combustors hence, eliminates the requirement for dilution of the feed gas to gas turbine combustors with excess air. It also improves the heating value of the feed gas to gas turbine combustors and allows mixing up with the flue gas from char combustor for an adjustment of the Wobbe Index of the gas turbine feed. The cost of electricity generation was predicted based on both no or nominal priced or reasonably priced $4^{\text {th }}$ generation biomass feedstock, agricultural waste like straws, using discounted cash flow and operating cost analyses for the two cases, without and with carbon capture respectively. The cost of electricity generation and the cost of carbon capture were estimated as a function of biomass feedstock cost and annualised capital cost, between which the cost of biomass feedstock is absolutely critical, which seems to suggest that CHP generation from biomass is economically viable with the help of low carbon initiatives such as Carbon Credits Trading and Climate Change Levy. The agricultural wastes 
currently associated with no or nominal price can be ideal feedstocks for CHP generation from biomass.

\section{Appendix A}

The RGibbs reactor option in Aspen Plus does not require reactions to be defined. However, for the sake of completeness to understand the biomass gasification process, here we presented a summary of reaction steps for two reactor modules for steam gasification of gases and tar and combustion of char respectively, in Figure A.1 As soon as the biomass particles come in contact with the hot fluidised gasifier bed (may comprise of catalyst particles), devolatilisation, which is also known as primary pyrolysis, occurs and gases are generated (Table 2 shows the composition of gases [28]). Mixing of biomass particles with steam (and oxygen in case of gasification with steam and oxygen) in order for homogeneous and heterogeneous reactions to happen is slower compared to the devolatilisation process. Hence, gases are first generated then undergone homogeneous reactions [Reaction set 1]. Cracking of tar results into gaseous and small straight chain molecules, which then react with steam (and oxygen in case of gasification with steam and oxygen) in homogeneous and heterogeneous reactions [Reaction sets 1 and 2 respectively]. The reactions for the cracking of tar presented as phenol are provided in Reaction set 3 [26]. Unreacted char is fully combusted in the presence of air.

\section{Reaction set 1}

Water gas shift: $\mathrm{CO}+\mathrm{H}_{2} \mathrm{O}=\mathrm{CO}_{2}+\mathrm{H}_{2}$

Methane reforming: $\mathrm{CH}_{4}+\mathrm{H}_{2} \mathrm{O}=\mathrm{CO}+3 \mathrm{H}_{2}$

Additional oxidation reactions if gasified with steam and oxygen:

$\mathrm{CH}_{4}+2 \mathrm{O}_{2}=\mathrm{CO}_{2}+2 \mathrm{H}_{2} \mathrm{O}$

$2 \mathrm{CO}+\mathrm{O}_{2}=2 \mathrm{CO}_{2}$

$2 \mathrm{H}_{2}+\mathrm{O}_{2}=2 \mathrm{H}_{2} \mathrm{O}$

Reaction set 2

Water gas: $\mathrm{C}+\mathrm{H}_{2} \mathrm{O}=\mathrm{CO}+\mathrm{H}_{2}$

Boudouard: $\mathrm{C}+\mathrm{CO}_{2}=2 \mathrm{CO}$

Methanation: $\mathrm{C}+2 \mathrm{H}_{2}=\mathrm{CH}_{4}$

Reaction set 3

$\mathrm{C}_{6} \mathrm{H}_{6} \mathrm{O}=\mathrm{CO}+0.4 \mathrm{C}_{10} \mathrm{H}_{8}+0.15 \mathrm{C}_{6} \mathrm{H}_{6}+0.1 \mathrm{CH}_{4}+0.75 \mathrm{H}_{2}$ 
$\mathrm{C}_{6} \mathrm{H}_{6} \mathrm{O}+3 \mathrm{H}_{2} \mathrm{O}=4 \mathrm{CO}+2 \mathrm{CH}_{4}+2 \mathrm{H}_{2}$

$\mathrm{C}_{10} \mathrm{H}_{8}=7.38 \mathrm{C}+0.275 \mathrm{C}_{6} \mathrm{H}_{6}+0.97 \mathrm{CH}_{4}+1.235 \mathrm{H}_{2}$

$\mathrm{C}_{6} \mathrm{H}_{6}+2 \mathrm{H}_{2} \mathrm{O}=1.5 \mathrm{C}+2.5 \mathrm{CH}_{4}+2 \mathrm{CO}$

$\mathrm{C}_{6} \mathrm{H}_{6} \mathrm{O}+4 \mathrm{O}_{2}=3 \mathrm{H}_{2} \mathrm{O}+6 \mathrm{CO}$

$\mathrm{C}_{6} \mathrm{H}_{6}+4.5 \mathrm{O}_{2}=6 \mathrm{CO}+3 \mathrm{H}_{2} \mathrm{O}$

$\mathrm{C}_{10} \mathrm{H}_{8}+7 \mathrm{O}_{2}=4 \mathrm{H}_{2} \mathrm{O}+10 \mathrm{CO}$

\section{References}

1. Dayton, D. C.; Chum, H. L. Energy Fuels 199610267268.

2. Beenackers, A. A. C. M. Renewable Energy 19991611801186.

3. Sadhukhan, J.; Zhu, X. X. Industrial \& Engineering Chemistry Research 20024115281544.

4. Bridgwater, A. V.; Evans, G. D. ETSU Report B/T1/00207/REP, UK Department of Trade \& Industry, 1993.

5. Milne, T. A.; Evans, R. J.; Abatzoglou, N.; National Renewable Energy Laboratory Report NREL/TP-570-25357, 1998.

6. Li, C.; Suzuki, K. Renewable and Sustainable Energy Reviews 200913594604.

7. Han, J.; Kim, H. Renewable and Sustainable Energy Reviews 200812397416.

8. Bridgwater, A. V. Fuel 199514631653.

9. Bridgwater, A. V.; Toft, A.J.; Brammer, J.G. Renewable and Sustainable Energy Reviews 20026 181248.

10. Craig, K. R.; Mann, M. K. National Renewable Energy Laboratory Report, NREL/TP-430-21657, 1996.

11. Overend, R. P.; Rivard, C. J. First Biomass Conference of the Americas, Golden Colorado: National Renewable Energy Laboratory; 474971993.

12. Palonen, J.; Lundqvist, R. G.; Stahl, K. VTT Symposium, 164, Espoo, 41541995.

13. Laihong, S.; Yang, G.; Xiao, J. Biomass and Bioenergy 200832120127.

14. Franco, C.; Pinto, F.; Gulyurtlu, I. Fuel 200382835842.

15. Leckner, B.; Werther, J. Energy Fuels 20001412861292.

16. http://www.gasification.org/Docs/1998_Papers/gtc9823.pdfS.

17. Murakami, T.; Xu, G.; Suda, T.; Matsuzawa, Y.; Tani, H.; Fujimori, T. Fuel 200786244255.

18. Ringer, M.; Putsche, V.; Scahill, J. National Renewable Energy Laboratory Report, NREL/TP510-37779, 2006. 
19. Quinkertz, R.; Ulma, A.; Gobrecht, E.; Wechsung, M. Power-Gen Asia, Kuala Lumpur, Malaysia, 21-23 October, 2008.

20. Townsa, B.; Skolnika, E. G.; Millera, J.; Scheferb, R. W.; Kellerb, J. O. Int. J. of Hydrogen Energy 20073230933099.

21. Williams, J. R.; Nelson, R. G.; Aller, T. D.; Claassen, M. M.; Rice, C. W. American Agricultural Economics Association Meetings, Long Beach, California, 28-31 July, 2002.

22. Lou, Y.; Smith, R.; Sadhukhan, J. The AIChE Spring National Meeting, New Orleans, 6-10 April, 2008.

23. http://www.uop.com/objects/92SelexCokeGasifAmm.pdf

24. Shah, M.; Raybold, T.; Jamal, A.; Drnevich, R.; Bonaquist, D.; Jones, R.; Gasification Technology Conference, San Francisco, 9-12 October, 2005.

25. Smith, R. Chemical Process Design and Integration, John Wiley \& Sons Ltd., 2005.

26. Nikoo, M. B.; Mahinpey, N. Biomass and Bioenergy 20083212451254.

27. Vagia, E. C.; Lemonidou, A. A. Int. J. of Hydrogen Energy 20083324892500.

28. Peijun, J.; Feng, W.; Chen, B. Chem. Eng. Sci. 200964582592.

29. Gerun, L.; Paraschiv, M.; Vîjeu, R.; Bellettre, J.; Tazerout, M.; GBbel, B.; Henriksen,U. Fuel 2008 8713831393.

30. Gil, J.; Corella, J.; Aznar, M. P.; Caballero, M. A. Biomass Bioenergy 199917389403.

31. Sousa, L. C. R. Technische Wissenschaften ETH Zurich, 2001.

32. Houben, M. P. Analysis of Tar Removal in a Partial Oxidation Burner. The dissertation of Eindhoven University, 2004.

33. Panigrahi, S.; Dalai, A. K.; Chaudhari, S. T.; Bakhshi, N. N. Energy Fuels 200317637642.

34. Courson, C.; Makaga, E.; Petit, C.; Kiennemann, A. Catalysis Today 200063427437.

35. Wu, Z. S.; Wu, C. Z.; Huang, H. T.; Zheng, S. P.; Dai, X. W. Energy Fuels 200317619624.

36. Aznar, M. P.; Caballero, M. A.; Gil, J.; Martin, J. A.; Corella, J. Ind. Eng. Chem. Res. 199837 266880.

37. Corella, J.; Orio, A.; Aznar, P. Ind. Eng. Chem. Res. 19983746174624.

38. Delgado, J.; Aznar, M. P. Ind. Eng. Chem. Res. 19973615351543.

39. Mitchell, C. P.; Hudson, J. B.; Gardner, D. N. A.; Storry, P. G. S.; Gray, I. M. Energy Technology Support Unit report ETSU B 1176-P1, Harwell: ETSU, 1990.

40. Rodrigues, M.; Andre, P. C.; Faaij, A. W. Energy 20032812291258.

41. Faaij, A.; Meuleman, B.; Van Ree, R. EWAB 9840. Utrecht Netherlands, 1998.

42. Sinnott, R. K. Coulson and Richardson's Chemical Engineering Series: Chemical Engineering Design Oxford: Elsevier Butterworth-Heinemann, 6, 252, 2006. 
43. Simbeck, D. R.; Chang, E. National Renewable Energy Laboratory Technical Report No. NREL/SR-540-32525, California: SFA Pacific, Inc, 2002.

44. National Energy Technology Laboratory (NETL), DOE/NETL-2002/1169, 2002.

45. Intergovernmental Panel on Climate Change (IPCC), Cambridge University Press, 2005.

46. Bridwater, A. V.; Toft, A. J.; Brammer, J. G. Renewable and Sustainable Energy Reviews 20026 181248.

47. Lozowski, D. Business News, Chemical Engineering, 116, 1, 59, New York: Jan 2009.

48. Economic Indicators, Chemical Engineering. 106, 8, 49, New York: August, 1999.

49. Economic Indicators, Chemical Engineering. 105, 10, 207, New York: September, 1998.

50. Sadhukhan, J.; Mustafa, M. M.; Misailidis, N.; Mateos-Salvador, F.; Du, C.; Campbell, G. M. Chem. Eng. Sci. 200863503519.

51. Sadhukhan, J.; Smith, R. Comp. \& Chem. Eng. 200731535551.

52. Sadhukhan, J. 7th World Congress of Chemical Engineering, Glasgow, Scotland, 10-14 July, 2005.

53. International Energy Agency (IEA), Report No. PH4/19, IEA, 2003.

54. USDA Foreign Agricultural Service, Global Agricultural Information Network report no: RP7029, Philippines bio-fuels annual, 2007.

55. Hamelinck, C. N.; Suurs, R. A. A.; Faaij, A. P. C. Biomass and Bioenergy 200529114134.

56. Argus global emissions: Volume VIII, 4 April 2009. www.argusmedia.com

57. DTI, Quarterly Energy Prices, London, UK, 2008. 


\section{Figures}

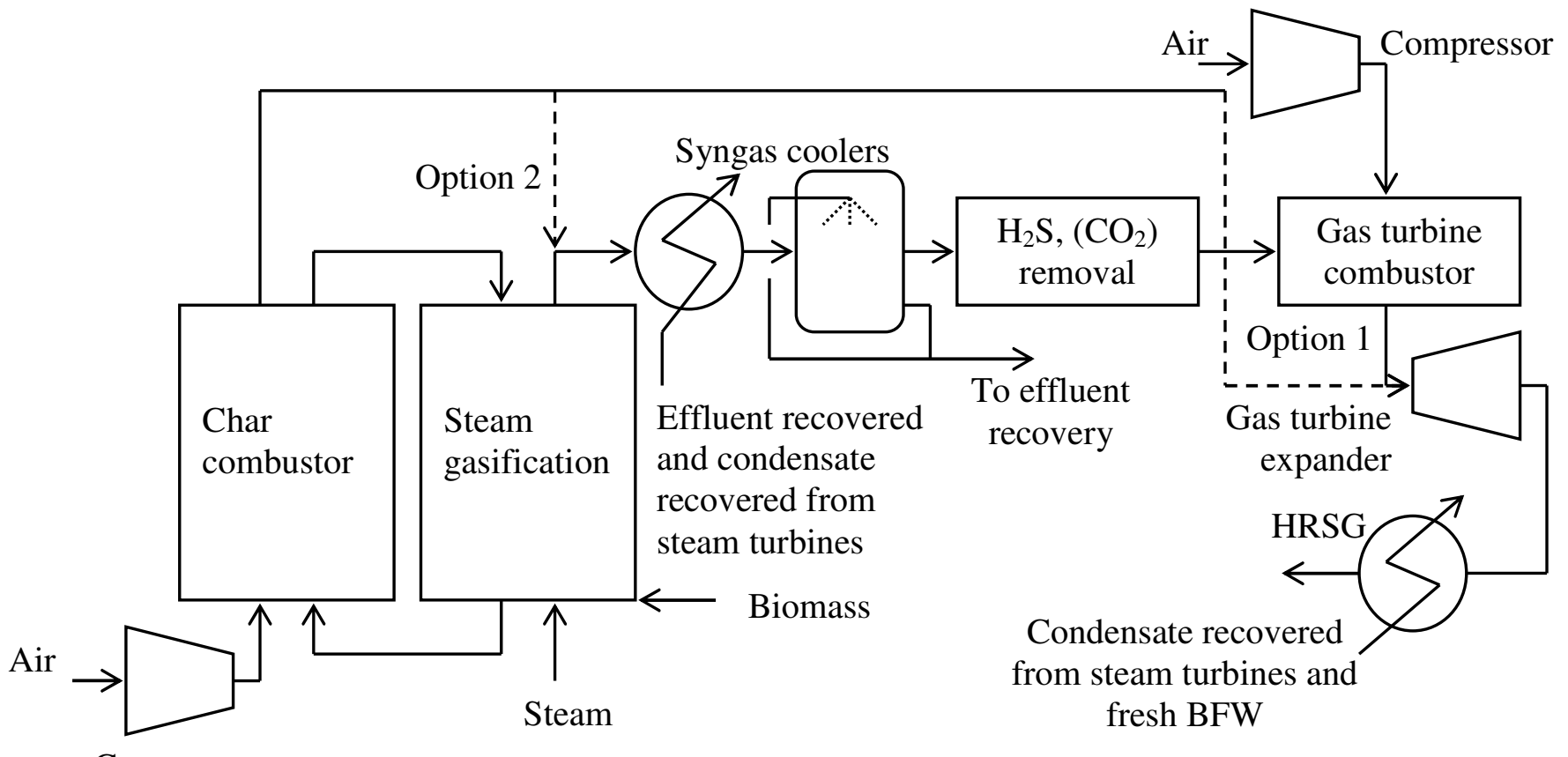

Compressor

Figure 1. Block diagram of biomass gasification based CHP flowsheet; Option 1: flue gas from char combustor injected to GT expander; Option 2: flue gas from char combustor mixed to syngas. $\mathrm{CO}_{2}$ removal is optional, which can be combined with $\mathrm{H}_{2} \mathrm{~S}$ removal 


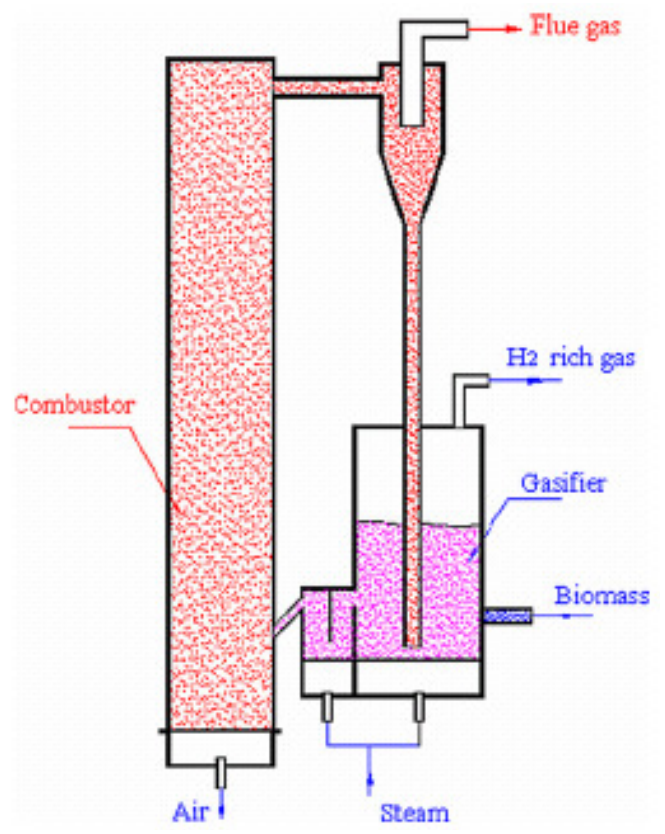

Figure 2. Schematic for interconnected fluidised bed gasifier with steam gasification and air driven char combustor [13] 


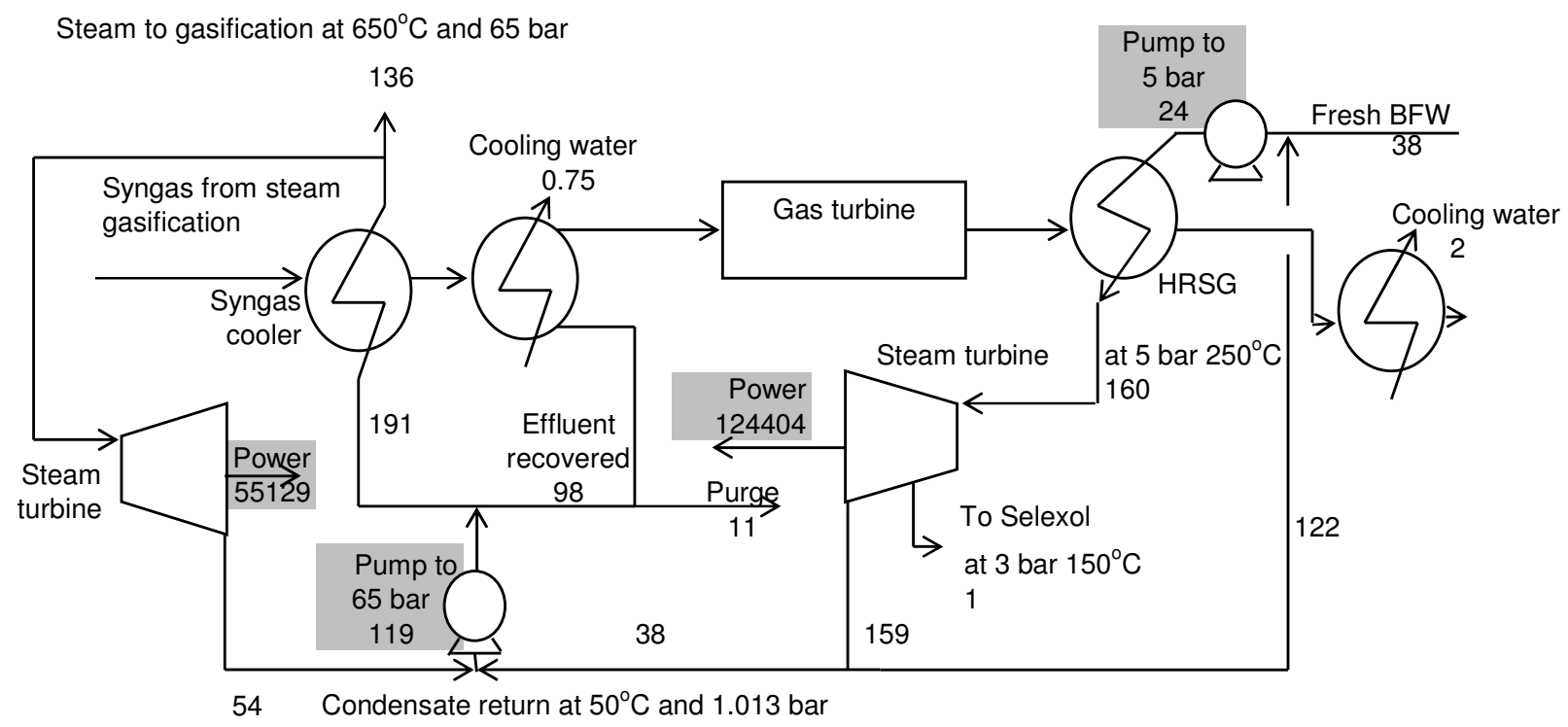

Figure 3. BFW (condensate) recovery-steam generation-steam turbine power network for straw based CHP flowsheet presented in Figure 1 Option 2: without any $\mathrm{CO}_{2}$ removal and with the flue gas from the char combustor added with the syngas from steam gasification; The flowrates of cooling water / $\mathrm{BFW} /$ steam are in $\mathrm{t} / \mathrm{hr}$, while the power generation / consumption (in shaded areas) is in $\mathrm{kW}$ 


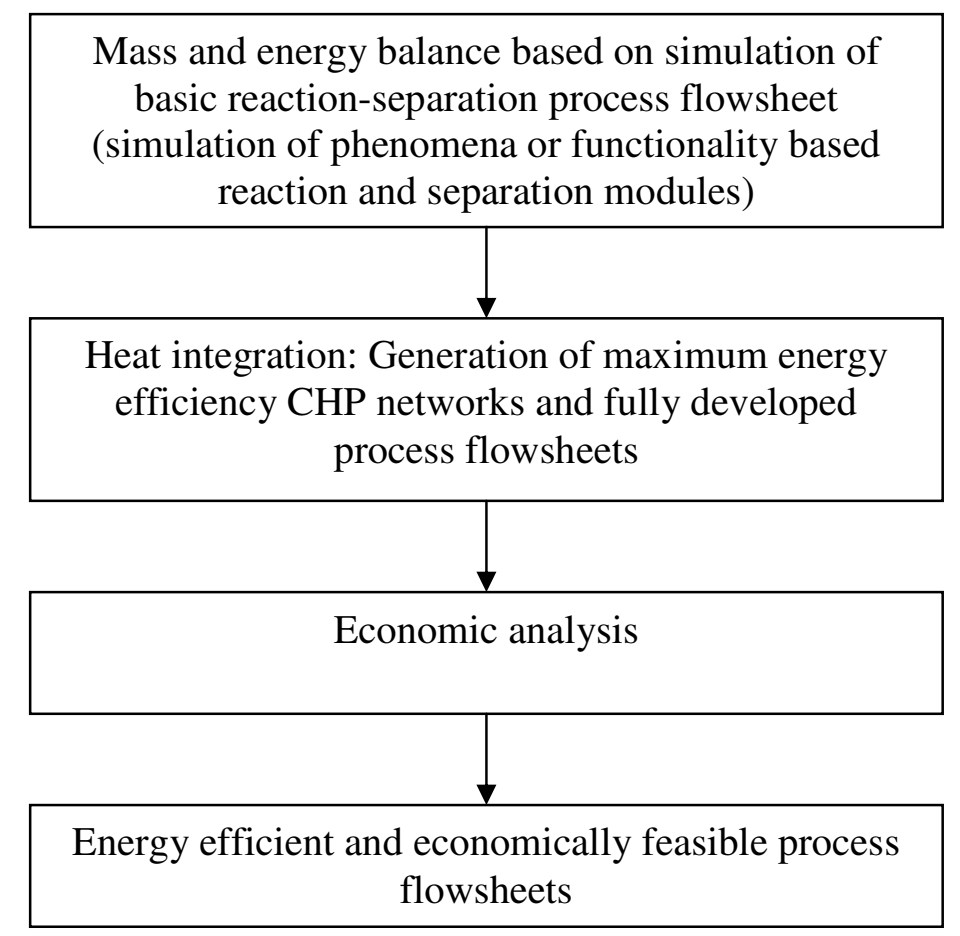

Figure 4. Proposed methodology to develop energy efficient and economically sustainable process flowsheets 


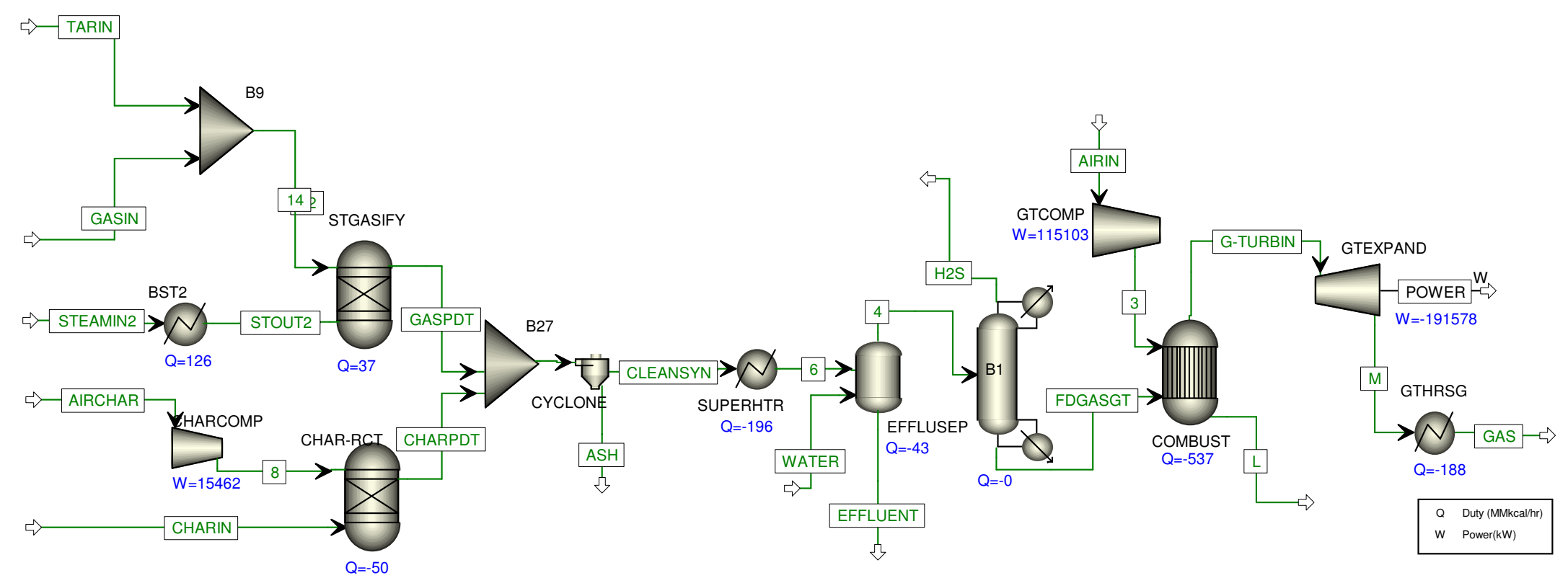

Figure 5. Simulation of biomass CHP flowsheet presented in Figure 1 Option 2: without any $\mathrm{CO}_{2}$ removal and with the flue gas from the char combustor added with the syngas from the steam gasifier. The main process modules are: steam gasification (STGASIFY), char combustor (CHAR-RCT), cyclone separator for removing ash (CYCLONE), syngas cooler (SUPERHTR), effluent recovery (EFFLUSEP), gas turbine combustor and expander (COMBUST and GTEXPAND respectively) and HRSG (GTHRSG). In addition, there are two air compressors for the char combustor and gas turbine respectively. 


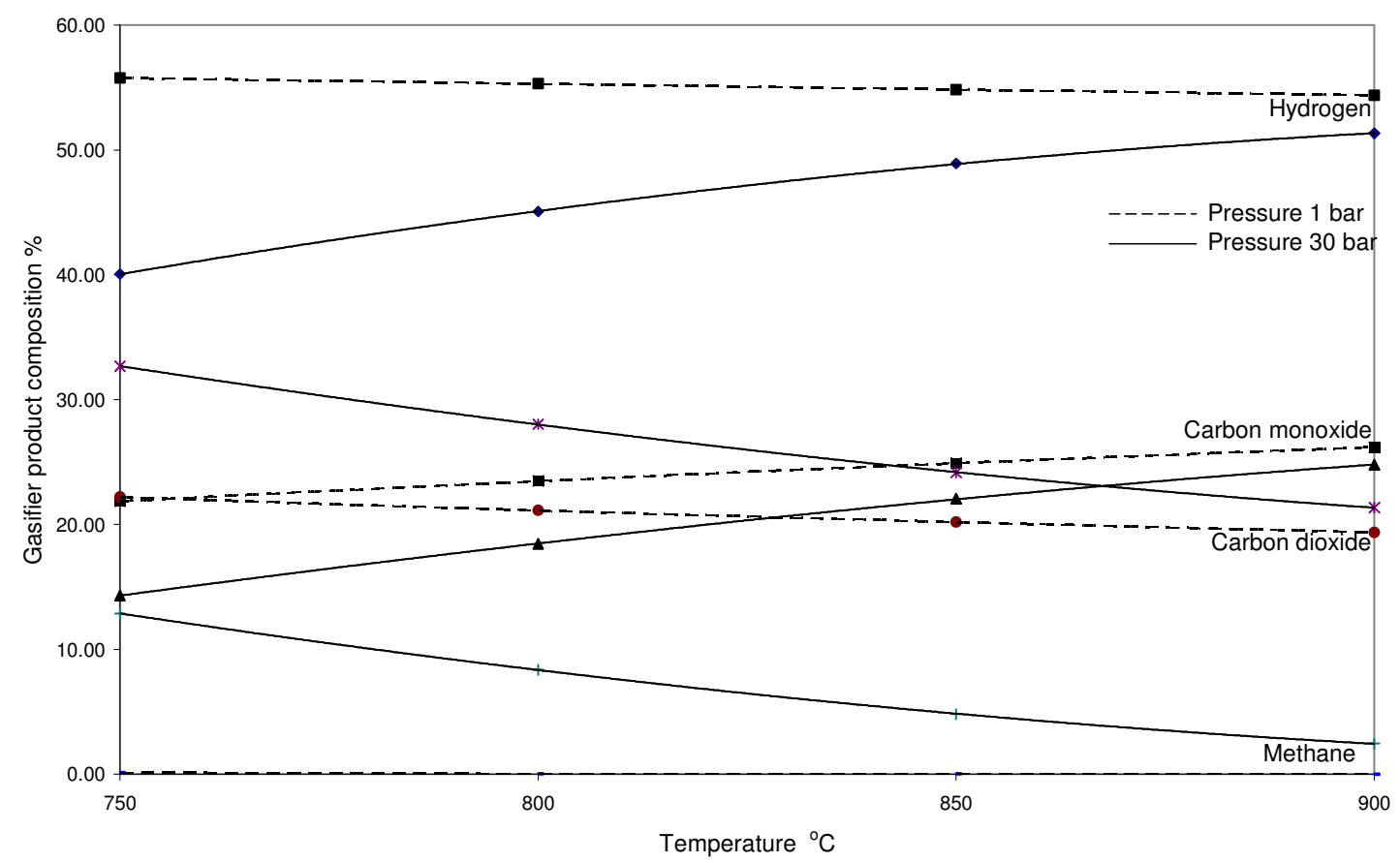

Figure 6. Variation of gasification product composition with temperature at two different pressures (based on straw as the biomass feedstock) 


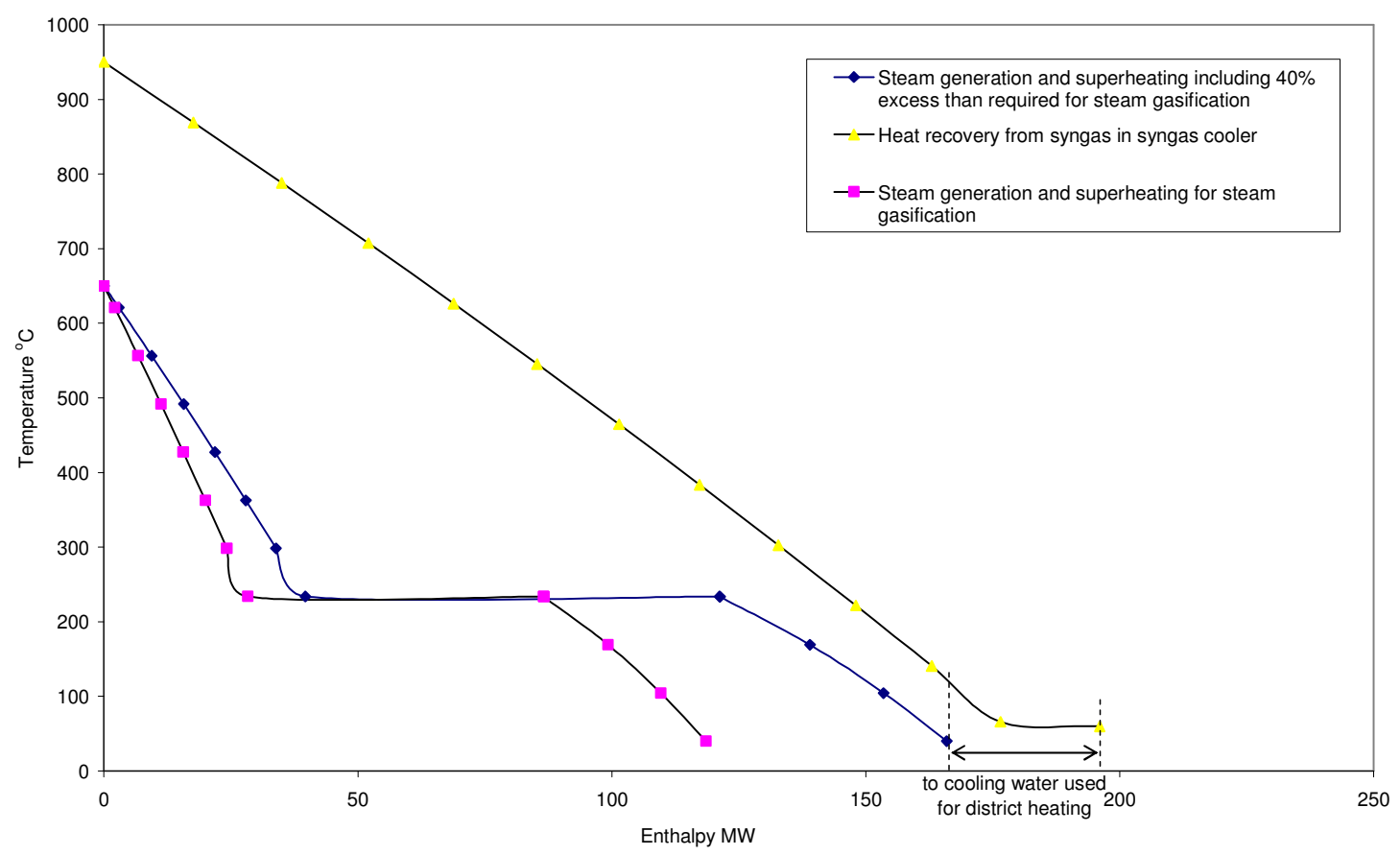

(a)

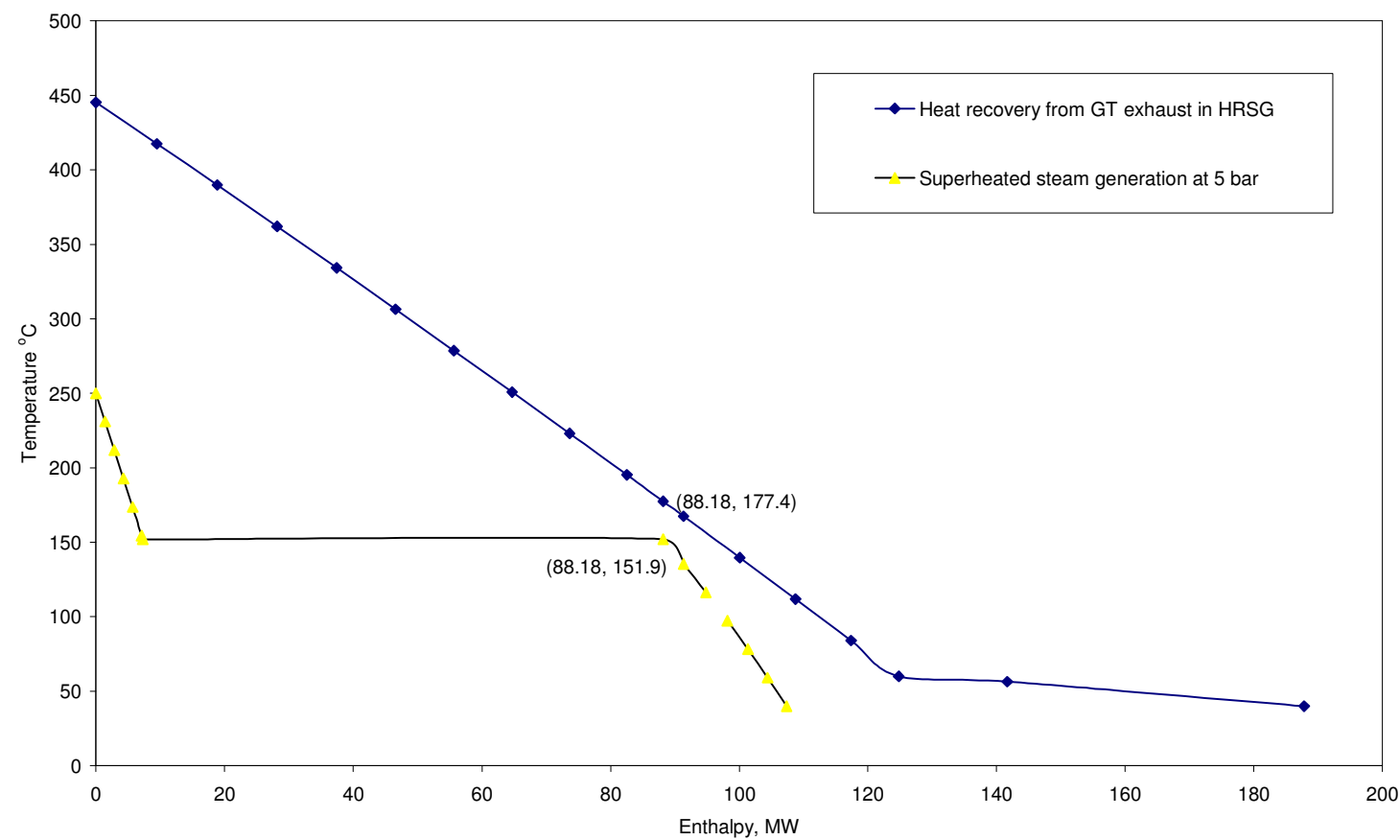

(b)

Figure 7. Steam generation (heat recovery) from (a) syngas cooler and (b)gas turbine exhaust for the flowsheet in Figure 1 Option 2: without any $\mathrm{CO}_{2}$ removal and with the flue gas from the char combustor added with the syngas from steam gasification (based on the straw as the biomass feedstock) 


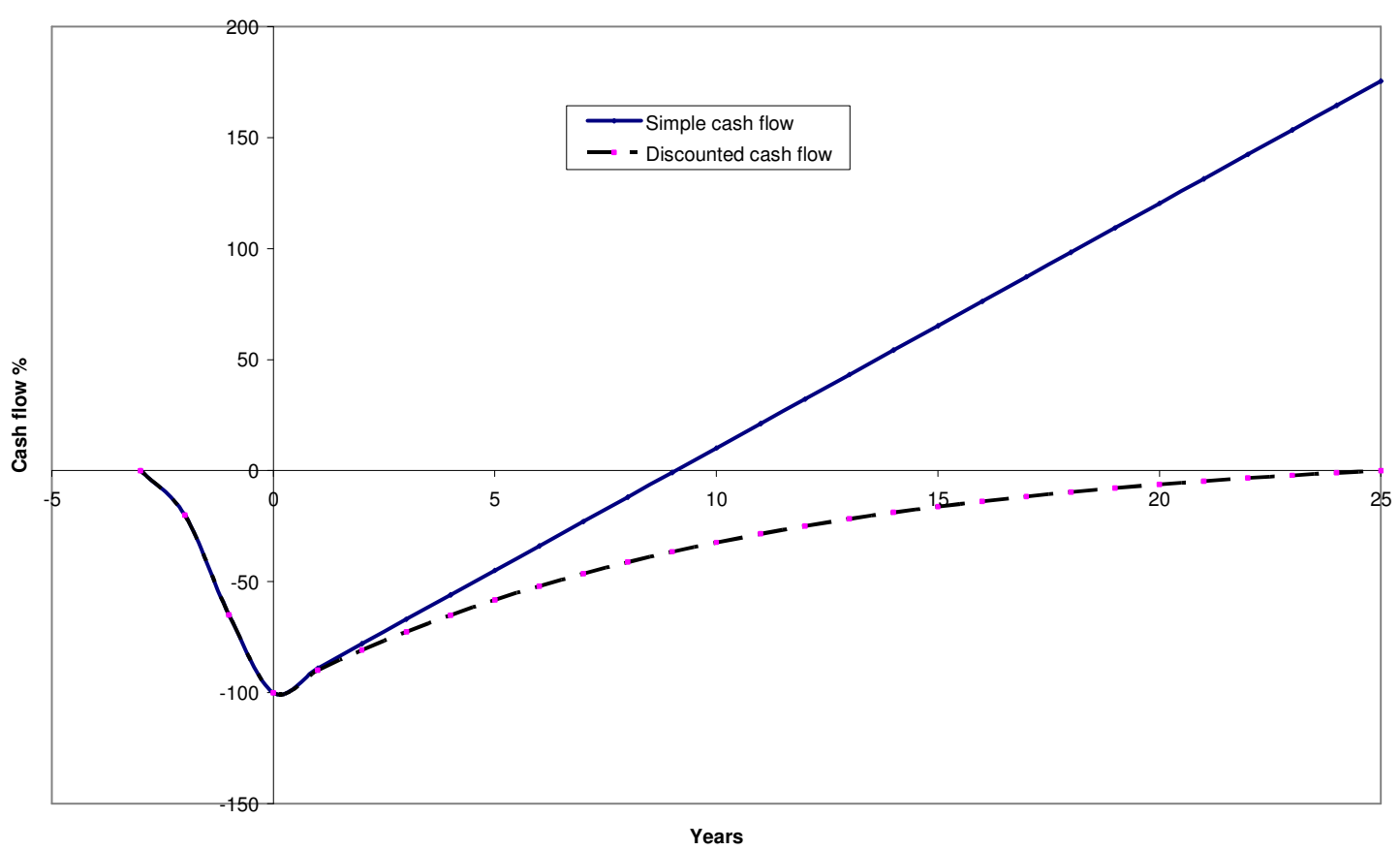

Figure 8. Simple and discounted cash flow analyses 


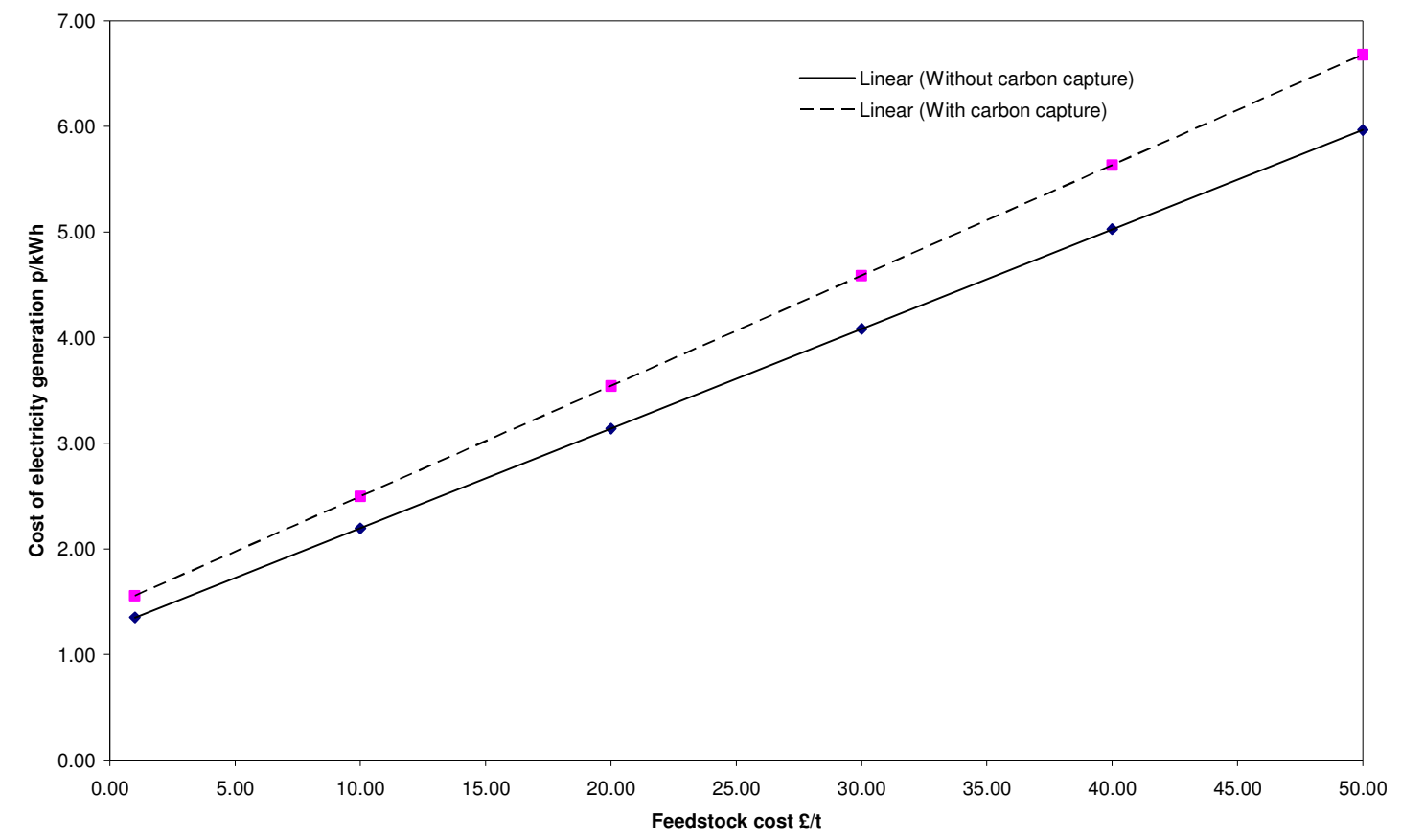

Figure 9. Cost of electricity generation with respect to feedstock price for the two cases with and without $\mathrm{CO}_{2}$ capture respectively (based on straw as the biomass feedstock) 


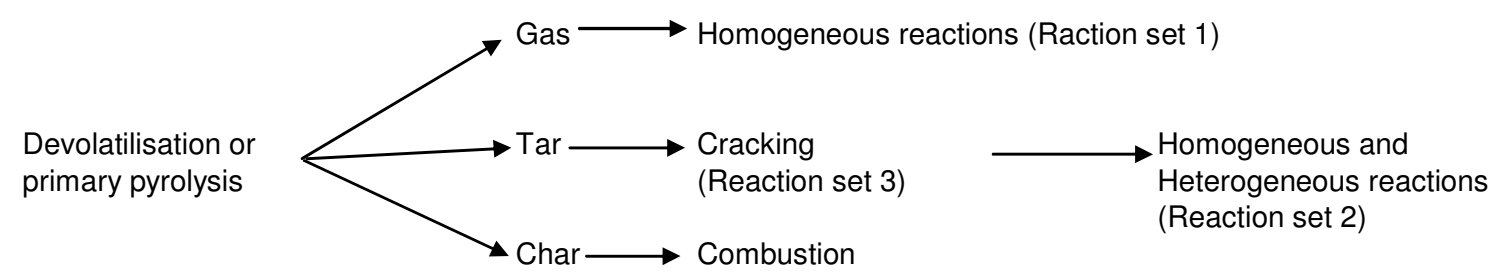

Figure A.1. Reaction steps in biomass gasification

\section{Tables}

Table 1. Operating conditions for various processes in biomass CHP plant

\begin{tabular}{|c|c|c|c|c|c|}
\hline \multirow[t]{2}{*}{ Process } & \multirow[t]{2}{*}{ Aspen model used } & \multicolumn{4}{|c|}{ Specifications } \\
\hline & & Temperature ${ }^{\circ} \mathrm{C}$ & Pressure bar & Compositions & $\begin{array}{l}\text { Any other } \\
\text { conditions }\end{array}$ \\
\hline Gasifier & $\begin{array}{c}\text { Gibbs reactor for } \\
\text { steam gasification and } \\
\text { char combustor }\end{array}$ & $>900$ & 30 & & \\
\hline Steam to gasification & & $<650$ & $>65$ & & $\begin{array}{c}\text { Steam to biomass } \\
\text { ratio: } 0.6\end{array}$ \\
\hline Gas after primary pyrolysis & Modeled as in Table 2 & $>900$ & 30 & According to Table 2 & \\
\hline Tar after primary pyrolysis & $\begin{array}{l}\text { 1) Ultimate analysis in } \\
\text { terms of carbon, } \\
\text { hydrogen and oxygen, } \\
\text { 2) Phenol }\end{array}$ & $>900$ & 30 & $\begin{array}{l}\text { 1) Based on ultimate } \\
\text { analysis, carbon, } \\
\text { hydrogen and oxygen } \\
\text { balance; } 2 \text { ) as Phenol }\end{array}$ & \\
\hline Char after primary pyrolysis & Carbon (Table 2) & $>900$ & 30 & According to Table 2 & \\
\hline Air & & 25 & 1.013 & $\begin{array}{c}\text { Nitrogen:Oxygen } \\
79: 21 \\
\end{array}$ & \\
\hline Stoichiometric oxygen & & & & & $\begin{array}{l}\text { To char combustor: } \\
21927 \mathrm{~kg} / \mathrm{hr} \\
\text { To GT combustor: } \\
925760 \mathrm{~kg} / \mathrm{hr} \\
\end{array}$ \\
\hline Air compressors & Compressor & exit pressure: & 30 & & Efficiency: 0.9 \\
\hline Syngas cooler & Cooler & exit: 60 & 30 & & \\
\hline \begin{tabular}{|l} 
Effluent recovery / \\
Direct quench \\
\end{tabular} & $\begin{array}{c}\text { Flash } \\
\text { separator }\end{array}$ & 50 & 30 & & \\
\hline $\begin{array}{l}\text { Steam to combined } \\
\mathrm{H}_{2} \mathrm{~S} \text { and } \mathrm{CO}_{2} \text { recovery }\end{array}$ & & 150 & 3 & & $\begin{array}{l}\mathrm{H}_{2} \mathrm{~S} \text { recovery: } 99 \% \\
\mathrm{CO}_{2} \text { recovery: } 90 \%\end{array}$ \\
\hline GT combustor & & 900 & 30 & & $\begin{array}{l}\text { Wobbe Index: } \\
9-11[9]\end{array}$ \\
\hline GT expander & Expander & & 1.05 & & Efficiency: 0.9 \\
\hline HRSG & Cooler & 50 & 1.013 & & \\
\hline $\begin{array}{l}\text { Turbines for steam generating } \\
\text { from syngas cooler }\end{array}$ & Expander & $\begin{array}{l}\text { inlet: } 650 \\
\text { condensate: }\end{array}$ & $\begin{array}{c}65 \\
1.013\end{array}$ & & \\
\hline $\begin{array}{l}\text { Turbines for steam generating } \\
\text { from syngas HRSG }\end{array}$ & Expander & $\begin{array}{l}\text { inlet: } 250 \\
\text { condensate: }\end{array}$ & $\begin{array}{c}5 \\
1.013 \\
\end{array}$ & & \\
\hline
\end{tabular}

Table 2. Gas composition and biomass breakup into gas, tar and char [28] 
Total gas

0.4760

$\mathrm{H} 2$

$\mathrm{CH} 4$

$\mathrm{C} 2$

$\mathrm{CO}$

$\mathrm{CO} 2$

$\mathrm{H} 2 \mathrm{O}$

Tar

Total devolatilization - total gas

Char
0.0016

0.0241

0.1227

0.2164

0.0308

0.0804

Table 3. Prediction of Wobbe Index

\begin{tabular}{lcllll}
\hline & \multicolumn{3}{l}{ Reference Wobbe Index [24] } & \multicolumn{2}{l}{ Figure 1 Option 2 case } \\
\hline Component & $\begin{array}{l}\mathrm{HHV} \\
\left(\mathrm{MJ} \mathrm{kg}^{-1}\right)\end{array}$ & Mole fraction & $\begin{array}{l}\mathrm{HHV} \times \\
\text { mole fraction }\end{array}$ & Mole fraction & $\begin{array}{l}\mathrm{HHV} \times \\
\text { mole fraction }\end{array}$ \\
\hline Case without $\mathrm{CO}_{2}$ capture & & & 0.44 & 62.43 \\
\hline $\mathrm{H}_{2}$ & 141.9 & 0.4 & 56.76 & 0.22 & 2.4 \\
$\mathrm{CO}$ & 10.9 & 0.2 & 2.18 & 0 & 0 \\
$\mathrm{CH}_{4}$ & 55.5 & 0.1 & 5.55 & SUM & 64.83 \\
& & SUM & 64.49 & Wobbe Index & 10.35 \\
\hline
\end{tabular}

Table 4. Capital cost evaluation for cases in Figure 1 Option 2 (based on straws as the biomass feedstock)

Present annual cost index value (Oct '08): 592.20

Items Original cost

Gasifier (inc char combustor)

Boilers (SYNGCOOL and HRSG)

$\mathrm{H}_{2} \mathrm{~S}$ removal unit

Cyclone

Gas turbine

Steam Turbine

syngas clean up

waste water treatment

feed handling and drying

Carbon capture and storage

Direct Production Costs (DPC)

General Facilities(Piping,heat exchangers,compressor,pumps)

Engineering, design,supervision

Management overheads

Installed Plant Cost (IPC)

Commissioning

Contingency

Contractors' fees

Interest during commission

Total Plant Cost (TPC)

20.28

2.42

1.63

6.01

30.00

3.30

13.89
0.43

4.44

4.44
4.44
Without $\mathrm{CO}_{2}$ capture With $\mathrm{CO}_{2}$ capture

$(\mathrm{m} £$ in year $\mathrm{t})$ Index value in year $\mathrm{t}$

389.50

395.60

389.50

395.60

395.60

389.50

361.30

357.60

468.2

$30 \%$ of DPC

$15 \%$ DPC

$10 \%$ DPC

$t$
1990
1998
2002
1998
2002
2002
1998
1991
1990
2005

1990
1998

2002

1998

1998

1991

2005

Present Cost $(\mathrm{m} £)$

$33.58 \quad 33.58$

$3.67 \quad 3.15$

$2.44 \quad 2.44$

$9.14 \quad 9.14$

$44.91 \quad 44.91$

$4.94 \quad 3.07$

$21.12 \quad 21.12$

$\begin{array}{ll}0.71 & 0.71\end{array}$

$\begin{array}{ll}7.35 & 7.35\end{array}$

$0.00 \quad 7.54$

$127.86 \quad 133.01$

$38.36 \quad 39.90$

$19.18 \quad 19.95$

$12.79 \quad 13.30$

31.97
33.25

$\begin{array}{lll}5 \% \mathrm{IPC} & 1.60 & 1.66\end{array}$

$10 \%$ IPC $3.20 \quad 3.33$

$10 \%$ IPC $\quad 3.20 \quad 3.33$

$10 \%$ IPC

3.20

3.33

209.37 
Table 5. Proximate and ultimate analyses of biomass feedstocks [13]

\begin{tabular}{lccr} 
Straws & \multicolumn{3}{c}{ Ultimate analysis $(\mathrm{wt} \%)$} \\
Proximate analysis $(\mathrm{wt} \%)$ & $\mathrm{C}$ & 36.57 \\
moisture & 8.50 & $\mathrm{H}$ & 4.91 \\
volatile matter & 64.98 & $\mathrm{O}$ & 40.70 \\
fixed C & 17.91 & $\mathrm{~N}$ & 0.57 \\
ash & 8.61 & $\mathrm{~S}$ & 0.14
\end{tabular}

$\underline{\text { Wood }}$

$\begin{array}{lccr} & \text { wt } \% & \text { Ultimate analysis (wt\%) } \\ \text { moisture } & 25.00 & \mathrm{C} & 51.80 \\ \text { (after long storage) } & & \mathrm{H} & 5.70 \\ & & \mathrm{O} & 40.90 \\ \text { ash (dry basis) } & 1.10 & \mathrm{~N} & 0.10 \\ \text { LHV (dry basis) } & 19.30 \mathrm{MJ} / \mathrm{kg} & \mathrm{S} & 0.00\end{array}$

Table 6. Composition (in mol fraction) of clean syngas feed to gas turbines for ${ }^{1}$ Option 1 and ${ }^{2}$ Option 2 (without carbon capture) in Figure 1

$\begin{array}{ccccc} & \text { Straw }^{1} & \text { Straw }^{2} & \text { Wood }^{1} & \text { Wood }^{2} \\ \mathrm{H}_{2} \mathrm{O} & 0.01 & 0.01 & 0.01 & 0.01 \\ \mathrm{~N}_{2} & 0.00 & 0.17 & 0.00 & 0.16 \\ \mathrm{H}_{2} & 0.56 & 0.44 & 0.57 & 0.46 \\ \mathrm{CO} & 0.28 & 0.22 & 0.28 & 0.23 \\ \mathrm{CO}_{2} & 0.14 & 0.15 & 0.13 & 0.14 \\ \mathrm{CH}_{4} & 0.01 & 0.01 & 0.01 & 0.01\end{array}$

Table 7. Net power and district heat generation or cooling water and BFW requirements and efficiency for the three cases depicted in Figure 1: Option 2 without $\mathrm{CO}_{2}$ removal, Option 1 and Option 2 with $\mathrm{CO}_{2}$ removal, respectively, in the three consecutive rows, with straws as the biomass feedstock

\begin{tabular}{|c|c|c|c|c|c|}
\hline $\begin{array}{c}\text { Net GT } \\
\text { power }\end{array}$ & $\begin{array}{c}\text { Net steam turbine power } \\
\text { MW }\end{array}$ & $\begin{array}{c}\text { District heating / } \\
\text { Cooling water }\end{array}$ & $\begin{array}{c}\text { BFW } \\
\text { requirement }\end{array}$ & Efficiency \\
\hline MW & Syngas cooler & HRSG & MW & t/hr & $\%$ \\
\hline 61.01 & 55.13 & 124.40 & 128.63 & 38.31 & 40.14 \\
\hline 71.83 & 24.81 & 117.06 & 126.40 & 37.95 & 36.97 \\
\hline 49.39 & 55.13 & 112.40 & 130.80 & 37.37 & 37.80 \\
\hline
\end{tabular}


Table 8. Economic comparison between the two cases depicted in Figure 1: Option 2 without $\mathrm{CO}_{2}$ and with $\mathrm{CO}_{2}$ removal, with straws as the biomass feedstock, respectively

\begin{tabular}{|c|c|c|c|c|c|c|c|}
\hline & Cost of BFW & Cost of cooling water & \begin{tabular}{|l|} 
Cost of feedstock \\
\end{tabular} & Tolling fees & Total cost & \multicolumn{2}{|c|}{ Cost of electricity } \\
\hline & £/year & £/year & £/year & £/year & $£ /$ year & $£ / G J$ & $\mathrm{p} / \mathrm{kWH}$ \\
\hline without $\mathrm{CO}_{2}$ capture & 107272.08 & 1105446.40 & 64048320.00 & 23030700.00 & 88291738.48 & 12.74 & 4.59 \\
\hline with $\mathrm{CO}_{2}$ capture & 104645.52 & 1124122.42 & 64048320.00 & 23958000.00 & 89235087.94 & 14.28 & 5.14 \\
\hline
\end{tabular}

